\title{
TAXONOMY OF RHEOPHILIC LUCIOBARBUS HECKEL, 1842 (ACTINOPTERYGII, CYPRINIDAE) FROM MOROCCO WITH THE DESCRIPTION OF TWO NEW SPECIES
}

\author{
I. Doadrio ${ }^{1 *}$, M. Casal-López ${ }^{1}$, S. Perea ${ }^{1}, \&$ A. Yahyaoui ${ }^{2}$ \\ ${ }^{1}$ Biodiversity and Evolutionary Group, Museo Nacional de Ciencias Naturales, CSIC. \\ C/José Gutiérrez Abascal, 2, 28006 Madrid, Spain \\ ID: http://lsid:zoobank.org:author:1514FE9E-2AA2-46D1-BB43-51F5E8EF1566 \\ MC-L: http://lsid:zoobank.org:author:84DEBB1B-A34C-412A-B03B-C3492A4E59BE \\ SP: http://lsid:zoobank.org:author:75C3112F-5BE9-4512-A9DB-DDA2A10497C7 \\ ${ }^{2}$ Laboratory of Zoology and General Biology, Faculty of Sciences, Mohammed V. University B.P. 1014 Rabat, Morocco \\ AY: http://lsid:zoobank.org:author:EA344560-EOFA-4D5D-A51C-23771D124D4B \\ * Corresponding author: doadrio@mncn.csic.es
}

\begin{abstract}
The genus Luciobarbus Heckel, 1843 is characterized by medium to large fish species occurring in large rivers and downstream zones with slow-moving waters. Remarkably also rheophilic Luciobarbus occur in Morocco, which are of small size and exhibit distinct morphological traits as well as different habitat requirements. These rheophilic species have traditionally been assigned to Luciobarbus nasus (Günther, 1874) and L. magniatlantis (Pellegrin, 1919), although some authors consider $L$. magniatlantis as a junior synonym of $L$. nasus. This lack of consensus on the taxonomy of rheophilic barbs is constrained by limited population studies that do not encompass their entire distribution range. Using molecular, morphometric, and osteological data we studied populations of rheophilic barbs of three drainage basins in which they are currently present: Tensift, Moulouya and Oum er Rbia. Our results clearly identified the rheophilic barbs of each basin as different species. The species Luciobarbus magniatlantis is a well-recognized species endemic to Tensift Basin. In contrast, the investigated populations from the Moulouya and Oum er Rbia basins could not be assigned to any previously described species. Consequently, we describe two new Luciobarbus species in the Moulouya and Oum er Rbia basins.
\end{abstract}

http://lsid:zoobank.org:pub:2494C25A-F4CB-41A1-B6C5-C124D14FD8C4

Key words: North Africa; Luciobarbus; Systematics; mtDNA; morphology.

\section{RESUMEN}

Taxonomía de las especies reófilas del género Luciobarbus Heckel, 1842 (Actinopterygii, Cyprinidae) de Marruecos con la descripción de dos nuevas especies

El género Luciobarbus Heckel, 1843 se caracteriza por presentar especies de medio y gran tamaño que viven en las zonas bajas de grandes ríos con aguas lentas. Singularmente, en Marruecos también existen especies reófilas del género Luciobarbus de pequeño tamaño y que presentan diferentes caracteres morfológicos y distintos requerimientos de hábitat. Estas especies reófilas han sido tradicionalmente asignadas a Luciobarbus nasus (Günther, 1874) y L. magniatlantis (Pellegrin, 1919) aunque algunos autores consideran a L. magniatlantis como un sinónimo de L. nasus. Esta falta de consenso en la taxonomía de los barbos reófilos está limitada por los escasos estudios poblacionales realizados que no abarcan la totalidad del área de distribución de estos barbos. Nosotros, usando datos moleculares, morfométricos y osteológicos, estudiamos las poblaciones de los barbos reófilos de tres cuencas hidrográficas, en las cuales están actualmente presentes: Tensift, Moulouya y Oum er Rbia. Nuestros resultados claramente identifican a los barbos reófilos de cada una de estas cuencas como diferentes especies. La especie L. magniatlantis es una especie bien definida y endémica de la cuenca del Tensift. En contraste, las poblaciones analizadas de las cuencas del Moulouya y Oum er Rbia no pudieron ser asignadas a ninguna especie previamente descrita. Consecuentemente, nosotros describimos dos nuevas especies de Luciobarbus en las cuencas del Moulouya y del Oum er Rbia.

Palabras clave: Norte de África; Luciobarbus; Sistemática; ADN mitocondrial; morfología. 
Cómo citar este artículo/Citation: Doadrio, I., Casal-López, M., Perea, S. \& Yahyaoui, A. 2016. Taxonomy of rheophilic Luciobarbus Heckel, 1842 (Actinopterygii, Cyprinidae) from Morocco with the description of two new species. Graellsia, 72(1): e039. http://dx.doi.org/10.3989/graellsia.2016.v72.153

Copyright: (C) 2016 SAM y CSIC. Salvo indicación contraria, todos los contenidos de la edición electrónica de Graellsia se distribuyen bajo licencia de uso y distribución Creative Commons Reconocimiento no Comercial 3.0. España (cc-by-nc).

\section{Introduction}

The genus Luciobarbus Heckel, 1843 comprises more than 30 species of medium to large size widely distributed along rivers draining into the Persian Gulf and the Mediterranean, Caspian, and Black seas (Doadrio, 1994; Kottelat \& Freyhof, 2007). With approximately 20 species, North Africa and the Iberian Peninsula show the highest diversity in Luciobarbus populations, with the genus being one of the main component of the freshwater fish fauna of these regions (Doadrio, 1994; Machordom et al., 1995). Phylogenetic studies using morphological characters, have provided evidence for Luciobarbus monophyly (Doadrio, 1990), but monophyly has not been unambiguously retrieved by molecular markers, due to the position of the genus Capoeta within Luciobarbus (Levin et al., 2012; Yang et al., 2015). The genera Capoeta and Luciobarbus comprise limnetic species, most of which migrate upstream to spawning areas, characterized by the presence of gravel and clear waters (Banarescu, 1999; Doadrio et al., 2011). Although they can survive in a variety of habitats, outside of the reproductive period they are most abundant in downstream areas. Remarkably, in the freshwaters of Morocco rheophilic Luciobarbus species can also be found, which have habitat requirements and morphological traits that differ from other Luciobarbus species (Doadrio, 1990).

The rheophilic species of Luciobarbus are sympatric with limnetic Luciobarbus and Carasobarbus species in rivers of the Atlas Mountains in Morocco (Doadrio, 1994), but their habitat is restricted to riffle areas, while other Atlas Mountain Luciobarbus are more widespread, with preference for slower waters (Doadrio 1990). The rheophilic Luciobarbus in Morocco have been assigned, so far, to two species: Luciobarbus nasus (Günther, 1874) and Luciobarbus magniatlantis (Pellegrin, 1919), which are morphologically characterized, with respect to other Luciobarbus species, by size rarely reaching $20 \mathrm{~cm}$ standard length; thick barbels placed at the extreme anterior of the snout; and males with equal-sized nuptial tubercles uniformly distributed over the body (Almaça, 1970; Doadrio, 1990). This difference in morphology placed L. nasus and L. magniatlantis in an unresolved taxonomic position, and they could not be assigned to Luciobarbus when the genus was formally defined on the basis of osteological traits (Doadrio, 1990). Subsequently, molecular studies of mitochondrial genes have unambiguously placed the rheophilic L. nasus in the genus Luciobarbus together with other North African species (Machordom \& Doadrio, 2001a, 2001b).

Within rheophilic Luciobarbus from Morocco, the taxonomic position of $L$. magniatlantis remains unclear. This species has been traditionally considered a junior synonym of L. nasus (Estève, 1947; Lévêque \& Daget, 1984). However, several authors reported morphological traits that unequivocally separate the rheophilic Luciobarbus into two morphological types and consider L. magniatlantis as a separate species (Pellegrin, 1939; Almaça, 1970, 1971; Doadrio, 1990).

So far there were no available studies on the population structure of the rheophilic barbs of the four Moroccan basins in which they occur: Moulouya Basin, on the Mediterranean slope, and Oum er Rbia, Tensift, and Kasab basins, on the Atlantic slope (Almaça, 1970; Doadrio, 1994; Borkenhagen \& Krupp, 2013). This lack of population studies compounds confusion about the type locality of Luciobarbus nasus and has hindered the taxonomic work. While the type locality, Tensift Basin, of L. magniatlantis is not in question (Pellegrin, 1919), the type locality of $L$. nasus is unclear, because the two syntype specimens were preserved together with sea fishes from Mogador (Essaouira) on the seacoast of Morocco (Günther, 1874). It is probable that the two syntypes of Barbus nasus came from material collected in the Kasab River near Mogador by K. v. Fritsch and J. Rein in 1872 (Borkenhagen \& Krupp, 2013).

We review the taxonomy of rheophilic Luciobarbus from Morocco, investigating morphology and genetic traits of specimens from Moulouya, Tensift, and Oum er Rbia basins, where they have been previously reported (Almaça, 1970). The recognition of two new distinct taxonomic entities, lead us to the description of two new species of Luciobarbus for the freshwaters of Morocco.

\section{Material and Methods}

Our study of Luciobarbus populations was based on 15 specimens (14 males, one female) from Tensift Basin, 33 specimens (21 males, 12 females) from Oum er Rbia Basin, and 12 specimens (12 males) from Moulouya Basin (Fig. 1; Table 1). Material from Kasab Basin could not be collected despite consecutive efforts over the course of several years. The Kasab River has been intensively modified in recent years by anthropogenic pressure as a consequence of the touristic development of Essaouira (Mogador). 


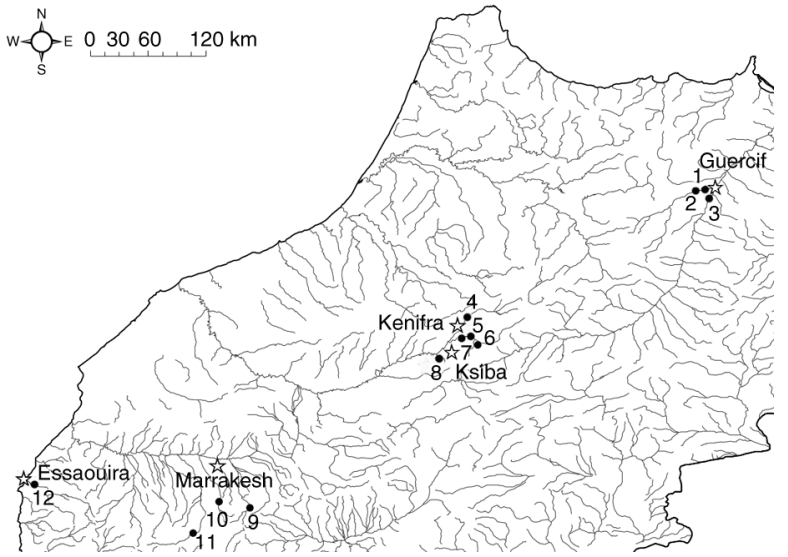

Fig. 1.- Sampling localities of Luciobarbus populations in Morocco. Melloul River, Guercif $(1,2)$; Moulouya R., Ghafoula (3); Oum er Rbia R., El Borj (4); Chbouka R., El Herri (5); Douna R., El Khemis (6); Serrou R., El Herri (7); Arba R., Ksiba (8); Ourika R., (9); Reraia R., Moulay Brahim (10); N'Fiss R., Kasbah Goundafi, and Imaounane (11); Kasab R., Essaouira (Former Mogador) (12)

Fig. 1.- Localidades de las poblaciones de Luciobarbus de Marruecos muestreadas. Río Melloul, Guercif $(1,2)$; Río Moulouya, Ghafoula (3); Río Oum er Rbia, El Borj (4); Río Chbouka, El Herri (5); Río Douna, El Khemis (6); Río Serrou, El Herri (7); Río Arba, Ksiba (8); Río Ourika, (9); Río Reraia, Moulay Brahim (10); Río N'Fiss, Kasbah Goundafi and Imaounane (11); Río Kasab, Essaouira (antiguo Mogador) (12).

Three cyprinid species were collected in the Kasab River during the past two decades: Luciobarbus ksibi (Boulenger, 1905), "Labeobarbus" reinii (Günther, 1874), and Carasobarbus fritschii (Günther, 1874). However, the endemic " $L$ ". reinii and $L$. nasus from the Kasab River have not been found in the past ten years, and it is likely that the species have disappeared or at least they are extremely rare. Therefore, our study of rheophilic Luciobarbus from the Kasab River was limited to the museum specimens of the two syntypes of Barbus nasus.

The material studied comprised the following specimens and locations: Tensift Basin: 3 specimens from the Reraia River, Moulay Brahim (31.2862, -7.9597), Morocco (voucher numbers: MNCN 280454-280456); 2 specimens from the N'Fiss River, Imaounane (30.9899, -8.2011), Morocco (voucher numbers: MNCN 208172280173); 7 specimens from the Ourika River, Morocco (voucher numbers: MNHN-IC-1919-0431-0437); Lectotype and Paralectotypes of Barbus magniatlantis Pellegrin, 1919; 3 specimens from N'Fiss River, Kasbah Goundafi (30.9899, -8.2011), Morocco (voucher numbers: MNHN-IC-1919-0438-040). Oum er Rbia Basin: 1 specimen from the Douna River, El Khemis (32.7508, -5.5416) Morocco, (voucher number: MNCN 55094); 2 specimens from the Serrou River, El Herri (32.8276, -5.6152), Morocco (voucher numbers: MNCN 208115-280116); 14 specimens from Arba River, Ksiba (32.5668, -6.0174), Morocco (voucher numbers: MNCN: 54987-55000); 9 specimens from the Oum er Rbia River, El Borj (33.0157, -5.6295),
Morocco (voucher numbers: MNCN 208168-208169; MNCN 71972-71978); 7 specimens from the Chbouka River, El Herri (32.8595, -5.6213), Morocco (voucher numbers: MNCN 279704-279707; MNCN 280083; MNCN 279695-279696). Moulouya Basin: 3 specimens from the Melloulou River, Guercif (34.2180, -3.3467 and 34.215, -3.3756), Morocco (voucher numbers: MNCN 286595-286596; MNCN-290831); 9 specimens from the Moulouya River, Ghafoula (34.145, -3.388), Morocco (voucher numbers: MNCN 290832-290840). Kasab Basin: 2 syntype specimens of Barbus nasus Günther, 1874 from the Kasab River preserved at the Natural History Museum (BMNH 1874.1.30.25-26).

All sampling sites (Fig. 1) presented similar riverine morphology, with clear water, rapid current and gravel bottom.

Twenty-four morphometric measurements were taken with digital callipers $(0.01 \mathrm{~mm})$, and ten meristic variables were counted with a stereoscopic microscope. The following acronyms were used for morphometric and meristic characters: A, number of anal fin rays; $\mathrm{AFH}$, anal fin height; $\mathrm{AFL}$, anal fin length; APL, anal peduncle length; BL1, first barbel length; BL2, second barbel length; BD, body depth; BLD, body least depth; $\mathrm{C}$, central caudal fin rays; CFL, caudal fin length; CPL, caudal peduncle length; D, dorsal fin rays, DFL dorsal fin length; DFH dorsal fin height; $\mathrm{ED}$, eye diameter; GR, gill rakers (number); HL, head length; IOW, interorbital width; LL lateral line scales; P, pectoral fin rays; PFL, pectoral fin length; PrAD, pre-anal distance; PrDD, pre-dorsal distance; PrOL, pre-orbital length; PrPD, pre-pectoral distance; PrVD, pre-ventral distance; PsOL, postorbital length; PVL, pectoral-ventral length; RSA, scale rows above lateral line; RSB scale rows below lateral line; SL, standard length; V, ventral fin rays; VFL, ventral fin length; VE, Number of vertebrae. The number of vertebrae was obtained by counting on X-ray images of specimens from all sampled populations. Osteological characteristics were investigated through computer tomography (CT) scan and digital dissection using VGStudio MAX v2.2 (Volume Graphics, http://www. volumegraphics.com).

After constructing the measurement matrix, Burnaby's method was used to correct for size effect. The Burnaby method removes the effects of a withinpopulation size-factor from between-group morphometric analyses through an orthogonal projection procedure (Burnaby, 1966; Röhlf \& Bookstein, 1987).

All analyses were conducted with the corrected matrix. Morphometric and meristic characters were analysed independently. To assess sexual dimorphism and to identify the variables that contributed most to the variation among populations, two principal component analyses (PCA) were performed using the covariance matrix for morphometric characters. Statistical analyses were carried out using PAST software (Hammer et al., 2001). 
Table 1.- Sampling localities for Luciobarbus from Moroccan and GenBank Accession numbers.

Tabla 1.- Localidades de muestreo para Luciobarbus de Marruecos y números de acceso de GenBank.

\begin{tabular}{|c|c|c|c|c|c|}
\hline Population assignment/species & Locality & $\begin{array}{l}\text { No. Individuals studied } \\
\text { Morphology/molecular }\end{array}$ & $\begin{array}{c}\text { Number in } \\
\text { Phylogenetic } \\
\text { tree }\end{array}$ & $\begin{array}{c}\text { GenBank } \\
\text { Accession } \\
\text { Numbers } \\
\end{array}$ & $\begin{array}{c}\text { Number } \\
\text { in map }\end{array}$ \\
\hline Moulouya population & $\begin{array}{l}\text { Melloulou R. Guercif/ } \\
\text { Moulouya Basin }\end{array}$ & $3 / 1$ & M3 & KU257527 & 1,2 \\
\hline Moulouya population & $\begin{array}{l}\text { Moulouya R. Ghafoula/ } \\
\text { Moulouya Basin }\end{array}$ & $9 / 3$ & M1, M2, M4 & $\begin{array}{l}\text { KU257525, } \\
\text { KU257526, } \\
\text { KU257528 }\end{array}$ & 3 \\
\hline Oum er Rbia population & $\begin{array}{l}\text { Oum er Rbia R. El Borj/Oum } \\
\text { er Rbia Basin }\end{array}$ & $9 / 3$ & $\mathrm{R} 1, \mathrm{R} 2, \mathrm{R} 3$ & $\begin{array}{l}\text { AY004744, } \\
\text { KU257531, } \\
\text { KU257532 }\end{array}$ & 4 \\
\hline Oum er Rbia population & $\begin{array}{l}\text { Chbouka R. El Herri/Oum er } \\
\text { Rbia Basin }\end{array}$ & $7 /-$ & & & 5 \\
\hline Oum er Rbia population & $\begin{array}{l}\text { Douna R. El Khemis/Oum er } \\
\text { Rbia Basin }\end{array}$ & $1 /-$ & & & 6 \\
\hline Oum er Rbia population & $\begin{array}{l}\text { Serrou R. El } \\
\text { Herri/Oum er Rbia Basin }\end{array}$ & $2 / 1$ & R4 & KU257533 & 7 \\
\hline Oum er Rbia population & $\begin{array}{l}\text { Arba R. Ksiba/Oum er } \\
\text { Rbia Basin }\end{array}$ & $14 /-$ & & & 8 \\
\hline $\begin{array}{l}\text { Tensift population. Lectotype and } \\
\text { Paralectotypes of Barbus magniatlantis }\end{array}$ & Ourika R./Tensift Basin & $7 /-$ & & $\mathrm{xxx}$ & 9 \\
\hline Tensift population & $\begin{array}{l}\text { Reraia R. Moulay Brahim/ } \\
\text { Tensift Basin }\end{array}$ & $3 / 2$ & Т2, Т3 & $\begin{array}{l}\text { KU257536, } \\
\text { KU257537 }\end{array}$ & 10 \\
\hline $\begin{array}{l}\text { Tensift population. Paralectotypes of } \\
\text { Barbus magniatlantis }\end{array}$ & $\begin{array}{l}\text { N'Fiss R. Kasbah Goudafi/ } \\
\text { Tensift Basin }\end{array}$ & $3 /-$ & & $\mathrm{xxx}$ & 11 \\
\hline Tensift population & $\begin{array}{l}\text { N'Fiss R. Imaounane/Tensift } \\
\text { Basin }\end{array}$ & $2 / 2$ & $\mathrm{~T} 1, \mathrm{~T} 4$ & $\begin{array}{l}\text { KU257534, } \\
\text { KU257535 }\end{array}$ & 11 \\
\hline $\begin{array}{l}\text { Kasab population. Syntypes of Barbus } \\
\text { nasus }\end{array}$ & $\begin{array}{l}\text { Kasab R. Essaouira/Kasab } \\
\text { Basin }\end{array}$ & $2 /-$ & & & 12 \\
\hline L. ksibi & Kasab R. /Kasab Basin. & $-/ 2$ & 1,2 & $\begin{array}{l}\text { KU257523, } \\
\text { KU257524 }\end{array}$ & 12 \\
\hline L. ksibi & Reraia R./Tensift basin & $-/ 2$ & 3,4 & $\begin{array}{l}\text { KU257538, } \\
\text { KU257539 }\end{array}$ & 10 \\
\hline L. ksibi & $\begin{array}{l}\text { Chbouka R./Oum er Rbia } \\
\text { basin }\end{array}$ & $-/ 2$ & 5,6 & $\begin{array}{l}\text { KU257529, } \\
\text { KU257530 }\end{array}$ & 5 \\
\hline L. bocagei & Duratón R./Duero Basin & $-/ 1$ & & & \\
\hline L. comizo & Tajo R./Tajo Basin & $-/ 1$ & & & \\
\hline L. grael/sii & Irati R./Ebro Basin & $-/ 1$ & & & \\
\hline L. guiraonis & Turia R./Turia Basin & $-/ 1$ & & & \\
\hline L. microcephalus & Zujar R./Guadiana Basin & $/ 1$ & & & \\
\hline L. sclateri & Segura R./Segura Basin & $/ 1$ & & & \\
\hline L. setivimensis & Soumman R./Soumman Basin & $/ 1$ & & & \\
\hline
\end{tabular}

For molecular analyses, we obtained specimens of rheophilic Luciobarbus from Oum er Rbia, Tensift, and Moulouya basins along with the limnophilic L. ksibi from Oum er Rbia, Tensift and Kasab basins, (Table 1). Also, the Iberian species of Luciobarbus and L. setivimensis (Valenciennes, 1842) from Algeria were added. Aulopyge hueguelli Heckel, 1843 and Barbus meridionalis Risso, 1827 were selected as outgroups, based on previous phylogenetic analyses (Zardoya \& Doadrio, 1999). Total genomic DNA was extracted from fin-clip tissue using the commercial kit Biosprint15 for tissue and blood (Qiagen).
For each specimen, the complete region $(1140 \mathrm{bp})$ of the mitochondrial cytochrome b (cytb) was amplified. Primers and protocols used for PCR for cytb followed Machordom \& Doadrio (2001b). After checking PCR products on $1 \%$ agarose gels, they were purified by ExoSAP-IT ${ }^{\mathrm{TM}}$ (USB) and directly sequenced on MACROGEN service using a 3730XL DNA sequencer. Sequences were deposited in the GenBank database under accession numbers KU257523-KU257539.

Phylogenetic analyses were performed using Bayesian inference (BI) implemented in MrBayes v. 3.2 (Ronquist et al., 2012). The Akaike Information Criterion 
(Akaike, 1973) implemented in jModeltest (Posada, 2008) was used to determine the evolutionary model that best fit the data. In this case, TIM1+G model was selected. Bayesian inference was performed using two independent runs of four Markov Montecarlo coupled chains (MCMC) of $5 \times 10^{6}$ generations each to estimate the posterior probability distribution. Topologies were sampled every 100 generations, and a majority-rule consensus tree was estimated after discarding the first $10 \%$ of generations. The robustness of the clades was assessed using Bayesian posterior probabilities. The average uncorrected p-distances among Luciobarbus populations were calculated for the cytb gene using MEGA package v. 6.0 (Tamura et al., 2013).

\section{Results and Discussion}

\section{COMPARISON OF MORPHOLOGY AMONG POPULATIONS}

Due to the sexual dimorphism of Luciobarbus (Doadrio, 1990), and because few female specimens were available, we removed females from the subsequent morphological analyses. Non-parametric Kruskal-Wallis and Mann-Whitney post hoc comparison analyses were used to assess differences in size and body shape among populations (Appendix 1). No differences in SL were found among Luciobarbus populations. However we found significant differences in morphometric measures, with the exception of preventral and preanal distances, anal and dorsal fin lengths, pre and post-orbital distances, and caudal peduncle length (Appendix 1).

The population from Moulouya basin exhibited an elongated body shape with the smallest body depth of any studied population. The dorsal fin was placed slightly more anterior, and the predorsal distance was shorter, than in Tensift and Oum er Rbia populations. All fins in the Moulouya population were larger than the ones present in the remaining populations, with the height of the anal fin significantly bigger than in other populations, in some specimens reaching, or nearly reaching, the anterior rays of the caudal fin when folded. The population of Oum er Rbia Basin possessed the longest anal caudal peduncle. This population had a narrow skull, characterized by the lowest inter-orbital width. The population of Tensift Basin had the smallest head, with the head and prepectoral distances shorter than in Moulouya and Oum er Rbia populations. The deepest caudal peduncle was also found in the Tensift population. The fins in the Tensift population were significantly smaller than in Moulouya and Oum er Rbia populations. Some specimens of the Tensift population, belonging to paralectoypes of Barbus magniatlantis, presented three pairs of barbels, a characteristic that was not observed in any other populations. An overview of the general morphology of the analysed populations is illustrated in Figs. 2 and 3.
The number of scales along the lateral line (median=45), superior transverse line (median=7.5) and inferior transverse line (median $=5.5$ ) was significantly lower in the Moulouya population than in the Tensift and Oum er Rbia (Appendix 1). Scale number along the lateral line (median=51) and superior transverse line (median $=9.5$ ) were significantly higher in the Oum er Rbia population than in Tensift and Moulouya populations.

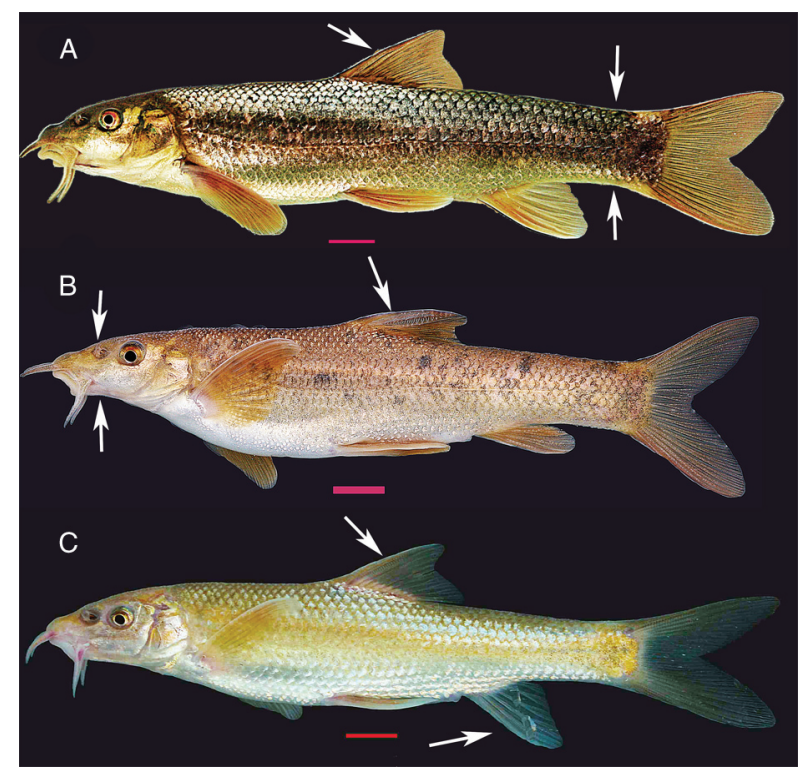

Fig. 2.- Morphology of the analysed populations. Arrows show principal traits of each population. A: Tensift Basin population; B: Oum er Rbia Basin; C: Moulouya Basin. Scale: $10 \mathrm{~mm}$.

Fig. 2.- Morfología de las poblaciones analizadas. Las flechas muestran los principales rasgos de cada población. A: población del Tensift; B: población del Oum er Rbia; C: población del Moulouya. Escala: $10 \mathrm{~mm}$.



Fig. 3.- Syntypes of Barbus nasus showing the characteristic deep caudal peduncle. Figure from the Natural History Museum (London).

Fig. 3.- Sintipos de Barbus nasus mostrando su característico y profundo pedúnculo caudal. Figura del Museo de Historia Natural de Londres. 


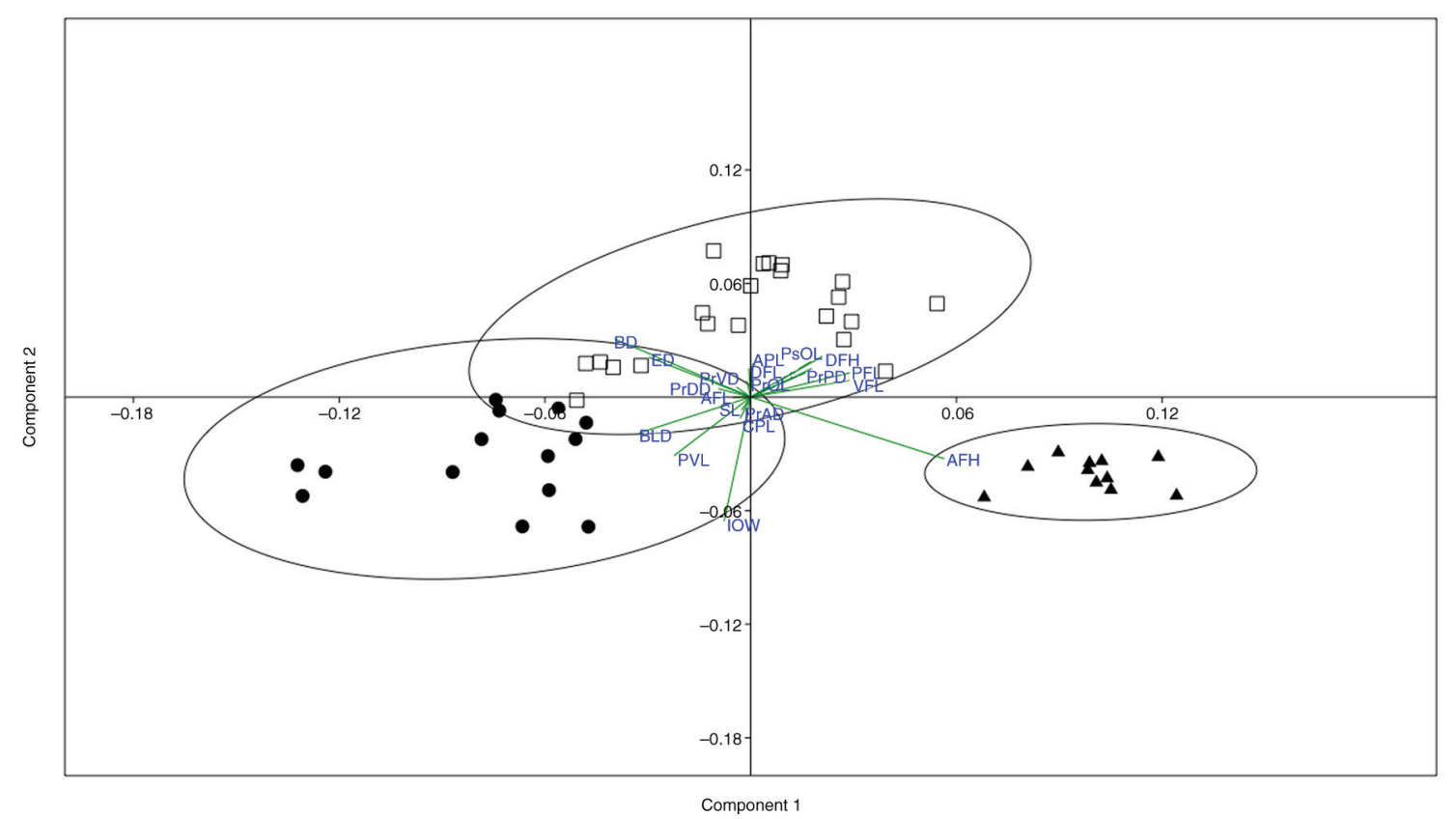

Fig. 4.- Variables that most contributed to the PCA analysis. Dots: Tensift population. Squares: Oum er Rbia population. Triangle: Moulouya population. Acronyms are defined in Materials and Methods.

Fig. 4.- Variables que más contribuyeron al análisis de PCA. Puntos: población del Tensift. Cuadrados: población del Oum er Rbia. Triángulo: población del Moulouya. Los acrónimos están definidos en la sección de Material y Métodos.

The principal component analysis (PCA) divided the specimens into three groups, corresponding to the populations of the three investigated basins (Fig. 4). The eigenvalues of the three first principal components, with the Burnaby-corrected matrix, explained most of the variance (Table 2). The highest eigenvector values (anal fin height and inter-orbital width) were in agreement with results of Kruskal-Wallis and Mann-Whitney analyses (Table 2).

\section{OSTEOLOGICAL FEATURES (APPENDIX 2)}

As shown by morphometric analyses, the skull of the Oum er Rbia population was narrower than the one present in Tensift and Moulouya populations. In particular, the ethmoid bone was longer and narrower (Appendix 2-1). In contrast, the kinethmoid bone of the Oum er Rbia population was shorter and more robust than in other populations (Appendix 2-2). The posterior branch of the lachrymal bone was elongated in the Oum er Rbia population and shorter in the Moulouya population (Appendix 2-3). The dentary bone was shorter in the Tensift population than in other populations (Appendix 2-4). The anterior process of the maxilla of the Tensift population was lesser developed than in Oum Er Rbia and Moulouya populations (Appendix 2-5). The number of pharyngeal teeth in Tensift, and Oum er Rbia populations was usually 4.3.2. As in other Luciobarbus species, the juveniles possessed five teeth in the external row. In the Tensift population, the fifth tooth was occasionally retained in the adults. In the Moulouya population, we found pharyngeal teeth in a 4.2.1 or 4.3.1 configuration (Appendix 2-6). The Oum er Rbia population had a thick inner branch of the pharyngeal bone, with reduced pharyngeal lamina. In the Tensift population, the superior branch of the pharyngeal bone was strongly flexed (Appendix 2-7). In Oum er Rbia populations, the last single ray of the dorsal fin was strongly ossified with a maximum width of $12-14.5 \%$ (median=13.8) of its height (Fig. 5). In Tensift (6.7-9.5\%, median=8.3) and Moulouya $(6.2-9.2 \%$, median $=7.4)$ populations, the last single ray of the dorsal fin showed a lower level of ossification (Fig. 5). The Tensift and Moulouya populations showed weaker denticulations in the last single ray of the dorsal fin, but higher denticulate density (Moulouya 3.1-2.4 teeth $/ \mathrm{mm}$, median $=2.6$ teeth $/ \mathrm{mm}$; Tensift 2.2-1.8 teeth $/ \mathrm{mm}$, median=2.1 teeth $/ \mathrm{mm}$ ) (Fig. 5). The population from Oum er Rbia had scarce and strong denticulations on the last single ray of the dorsal fin at a density of 1.1-1.4 teeth/mm, median=1.2 teeth $/ \mathrm{mm}$ (Fig. 5).

\section{MOLECULAR DATA}

The phylogenetic analysis using BI, with Aulopyge huegelli and Barbus meridionalis as outgroup taxa, revealed two main clades corresponding primarily to the Iberian and African species (Fig. 6). The Iberian group clustered with Luciobarbus setivimensis of Algeria, as was previously reported (Machordom \& Doadrio, 2001b). Unexpectedly, the populations of rheophilic Luciobarbus were not monophyletic, and the Moulouya Basin population was clustered with 
Table 2.- Eigenvalues and eigenvectors for the first three principal components (PC1-PC3) of 21 morphometric variables for all rheophilic Luciobarbus populations. Acronyms are defined in the Material and Methods section. Variables with the highest eigenvalues for each PC are in bold.

Tabla 2.- Eigenvalores y eigenvectors para los tres primeros componentes principales (CP1-CP3) de 21 variables morfométricas para todas las poblaciones de barbos reófilos. Los acrónimos están definidos en la sección de Material y Métodos. Las variables con los eigenvalores más altos para cada CP están en negrita.

\begin{tabular}{lccc}
\hline Variables & PCI & PCII & PCIII \\
\hline Eigenvalue & 0.0050 & 0.0019 & 0.0009 \\
\% variance & 46.48 & 18.05 & 8.85 \\
Eigenvectors & & & \\
SL & -0.2605 & -0.0678 & -0.1058 \\
PrDD & -0.0926 & 0.0432 & -0.1735 \\
PrPD & 0.1747 & 0.1477 & 0.0542 \\
PrVD & -0.0406 & 0.0515 & 0.0110 \\
PrAD & -0.0046 & -0.0412 & 0.0021 \\
PVL & -0.2190 & -0.3034 & -0.3745 \\
CPL & -0.0301 & -0.1112 & -0.3078 \\
APL & 0.0062 & 0.1765 & -0.3697 \\
BD & $-\mathbf{0 . 3 8 8 8}$ & $\mathbf{0 . 3 0 2}$ & 0.1404 \\
BLD & -0.3187 & -0.1862 & 0.0311 \\
HL & 0.1575 & 0.1267 & -0.1107 \\
PrOL & -0.0114 & 0.0839 & $\mathbf{0 . 4 1 1 9}$ \\
ED & -0.2916 & 0.2065 & 0.1496 \\
PsOL & 0.1731 & 0.1844 & -0.0512 \\
PFL & 0.2832 & 0.1257 & 0.1731 \\
VFL & 0.2832 & 0.0867 & 0.2835 \\
DFL & -0.0053 & 0.1496 & 0.1400 \\
DFH & 0.2053 & 0.2113 & -0.0097 \\
AFL & -0.0504 & -0.0029 & -01324 \\
AFH & $\mathbf{0 . 5 5 3 6}$ & $-\mathbf{0 . 3 1 9 4}$ & -0.1403 \\
IOW & -0.0760 & $-\mathbf{0 . 6 4 3 2}$ & $\mathbf{0 . 4 3 4 9}$ \\
\hline & & &
\end{tabular}

the Iberian group, while the populations from Oum er Rbia and Tensift basins constituted a monophyletic group with Luciobarbus ksibi from the same basins and from its type locality (Kasab River). The phylogenetical position of the Moulouya population within the Iberian group was not resolved.

Genetic distances within Moulouya, Oum er Rbia and Tensift populations of rheophilic barbels ranged from 0.1 to $0.3 \%$. The Moulouya population showed genetic distances from Tensift and Oum er Rbia populations ranging from 8.1 to $8.4 \%$. The genetic distances between Oum er Rbia and Tensift populations was $1.1 \%$ (Table 3). Genetic distances between limnophilic $L$. ksibi and rheophilic barbs of the same basins (Oum er Rbia and Tensift) were from 5.6 to $5.9 \%$. The genetic distances of Moulouya population with respect to other Luciobarbus species were similar or higher

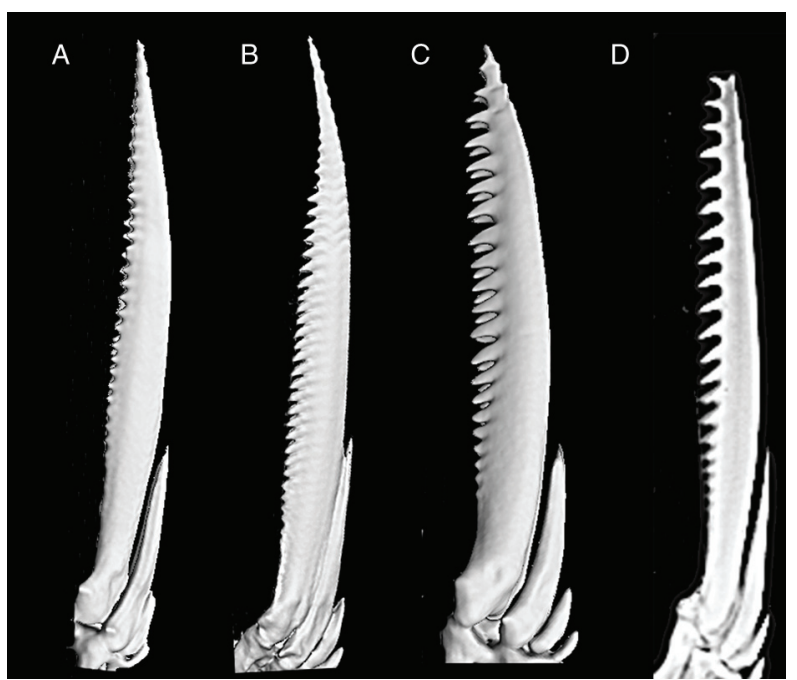

Fig. 5.- Denticulation of the last single ray of the dorsal fin in specimens of the populations from Tensift (A, SL $135.8 \mathrm{~mm}$ ), Moulouya (B, SL $139 \mathrm{~mm}$ ), Oum er Rbia (C, SL $126.5 \mathrm{~mm}$ ) and syntype of Barbus nasus (D, SL $108.7 \mathrm{~mm}$ ).

Fig. 5.- Último radio sencillo denticulado de la aleta dorsal en individuos de las poblaciones del Tensift (A, SL 135,8 mm), Moulouya (B, SL $139 \mathrm{~mm}$ ), Oum er Rbia (C, SL 126,5 mm) and sintipo de Barbus nasus (D, SL 108,7 mm).

than the ones reported to sister species of cyprinid fishes (Doadrio \& Carmona, 2003, 2006; Doadrio \& Madeira, 2004; Robalo et al., 2005; Doadrio \& Elvira, 2007; Domínguez-Domínguez et al., 2007, 2009). In contrast, genetic distances between Tensift and Oum er Rbia population were lower than the ones found in sister species of Luciobarbus (Casal-López et al., 2015).

\section{TAXONOMIC REMARKS}

The three studied populations from the Oum er Rbia, Moulouya, and Tensift basins possessed molecular, osteological, and morphometric traits that identified them as different species. The assignment of Oum er Rbia, Moulouya, and Tensift populations to the rheophilic species $L$. nasus was not possible, as the combination of diagnostic traits of L. nasus was not shared by the studied populations. The combination of the diagnostic traits of all populations and the syntypes of Barbus nasus are showed in Table 4. The population morphologically most similar to L. nasus was that of the Oum er Rbia Basin. Differences between the Oum er Rbia population and L. nasus were found, primarily in the morphology of the last single ray of the dorsal fin, number of scales in the lateral line, morphology of the pharyngeal teeth, kinethmoid bone shape and caudal peduncle depth. The maximum width of the last single dorsal fin ray of the syntype of Barbus nasus was $11.5 \%$ of its height, and does not reach the robustness of that of the Oum er Rbia population (12-14.5\%, median=13.8) (Fig. 5). The number of scales in the lateral line was 46-44 in Barbus nasus 


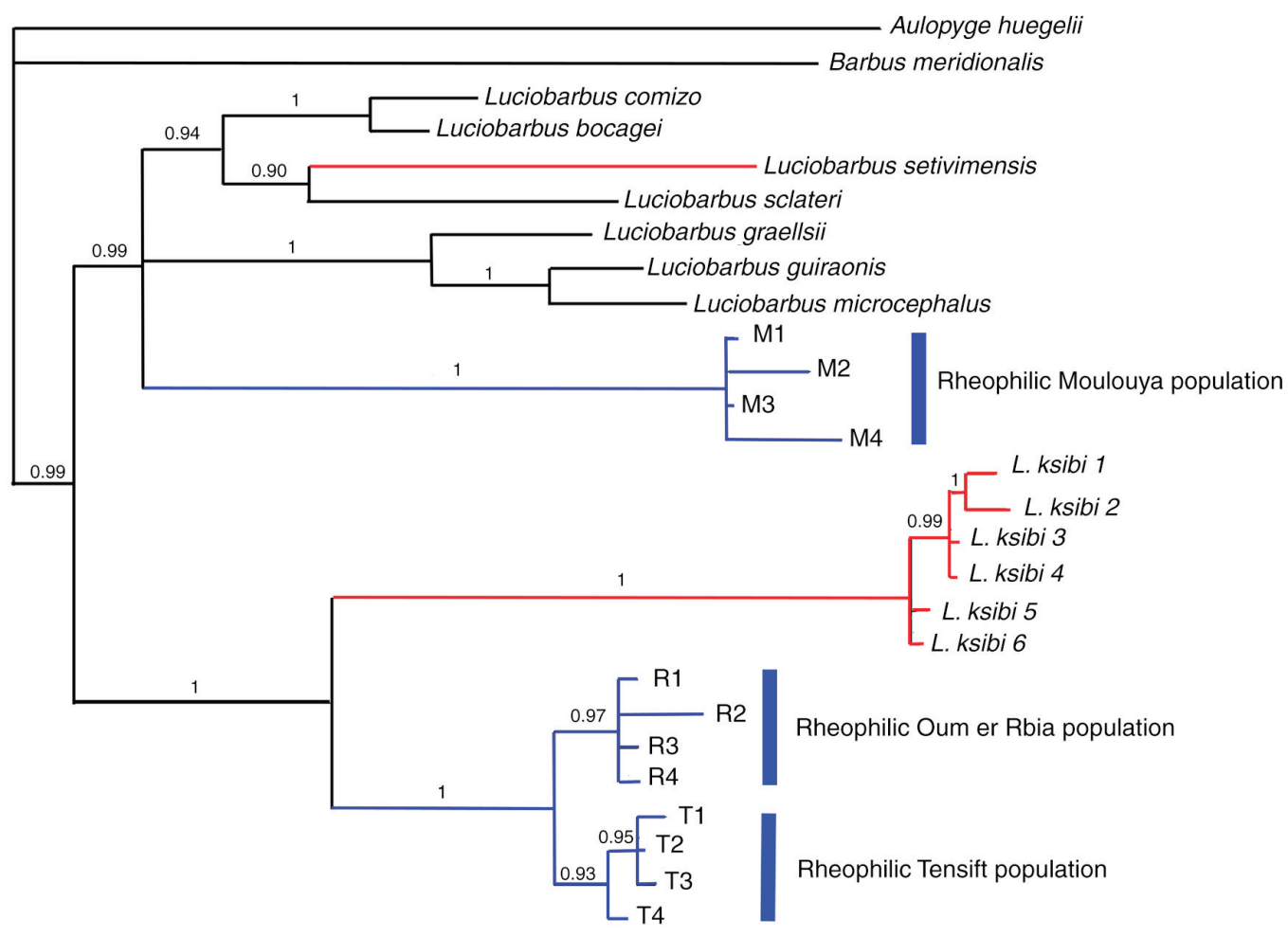

Fig. 6.- Phylogenetic tree rendered by Bayesian Inference of the mitochondrial cytochrome $b$ gene. Numbers on branches indicate posterior probability values. Identification of localities is defined in Table 1. Red branches show limnophilic North African species. Blue branches represent North African rheophilic populations.

Fig. 6.- Árbol filogenético del gen mitochondrial citocromo $b$ obtenido a partir de Inferencia Bayesiana. Los números sobre las ramas indican valores de probabilidad posterior. La identificación de las localidades está definida en la Tabla 1. Las ramas marcadas en rojo representan las especies limnófilas del Norte de África. Las ramas marcadas en azul señalan las poblaciones reófilas del Norte de África.

syntypes and $49-53$ scales $(\bar{x}=51$, median $=51)$ in Oum er Rbia population. Pharyngeal teeth and kinethmoid bone were more robusts in Oum er Rbia than in L. nasus (Appendix 2-2, 2-7). Anal peduncle length was less of two times the BLD while in Oum er Rbia population was always more of two times.

In the absence of molecular data and a greater number of specimens for morphological studies, L. nasus

Table 3.- Genetic distances for the complete mitochondrial cytb gene. Uncorrected-p genetic distances between species are below the diagonal. Uncorrected-p genetic distances within species are shown in the diagonal.

Tabla 3.- Distancias genéticas para el gen mitochondrial citocromo b completo. Las distancias genéticas no corregidas entre especies están debajo de la diagonal. Las distancias genéticas no corregidas dentro de las especies se muestran en la diagonal.

\begin{tabular}{lcccc}
\hline & Moulouya & Oum er Rbia & Tensift & L. ksibi \\
\hline Moulouya & 0.2 & & & \\
Oum er Rbia & 8.4 & 0.3 & & \\
Tensift & 8.1 & 1.1 & 0.1 & \\
L. ksibi & 9.1 & 5.9 & 5.7 & 0.5 \\
\hline
\end{tabular}

must be considered an endemic species of the Kasab Basin and L. magniatlantis an endemic species of the Tensift Basin.

The populations of Moulouya and Oum er Rbia basins exhibit multiple diagnostic traits differing from those of L. nasus and L. magniatlantis (Table 4).

\section{DESCRIPTION OF LUCIOBARBUS POPULATIONS}

The high degree of morphological and genetic differentiation of Luciobarbus populations endemic to the Moulouya and Oum er Rbia basins justifies the consideration of these population as distinct species. No available names for these populations exist, and therefore these are described as new species in the present study.

Luciobarbus guercifensis sp. nov. Doadrio, Perea \& Yahyaoui

http://1sid:zoobank.org:act:6DF6332F-F73B-437F-88E12F4AC7F15F4F

Holotype: Fig. 7, Table 5. MNCN 290835 male, 139.4 mm (SL); Moulouya River, Moulouya Basin, Ghafoula, Mediterranean slope in Morocco (34.14534, -3.38847) (Fig. 1); 22/6/2015. 378 ATSL, Collected by (Coll.) Doadrio, I; Yahyaoui, A and Perea, S. 
Table 4.- Diagnostic morphological characters of the four populations studied.

Tabla 4.- Caracteres morfológicos diagnósticos de las cuatro poblaciones estudiadas.

\begin{tabular}{|c|c|c|c|c|}
\hline & $\begin{array}{l}\text { Moulouya } \\
\text { population }\end{array}$ & $\begin{array}{c}\text { Oum er Rbia } \\
\text { population }\end{array}$ & $\begin{array}{c}\text { Tensift } \\
\text { L. magniatlantis }\end{array}$ & $\begin{array}{c}\text { Kasab } \\
\text { L. nasus }\end{array}$ \\
\hline $\begin{array}{l}\text { Width of the last single ray of } \\
\text { the dorsal fin }\end{array}$ & $<10 \%$ Height & $>10 \%$ Height & $<10 \%$ Height & $>10 \%$ Height \\
\hline $\begin{array}{l}\text { Denticulations of the last single } \\
\text { ray of the dorsal fin }\end{array}$ & $\begin{array}{l}\text { Profusely serrated } \\
24-26 \text { denticulations } \\
\text { in adults }\end{array}$ & $\begin{array}{l}\text { Sparsely serrated } \\
11-13 \text { denticulations } \\
\text { in adults }\end{array}$ & $\begin{array}{l}\text { Profusely serrated } \\
18-22 \text { denticulations } \\
\text { in adults }\end{array}$ & $\begin{array}{l}\text { Sparsely serrated } \\
20-21<25 \text { denticulations } \\
\text { in adults }\end{array}$ \\
\hline No. scales in lateral line & $45-48 \leq 48$ & $49-53>48$ & $51-47 \leq 48$ & $44-46 \leq 48$ \\
\hline No. scales above lateral line & $6.5-8.5$ & $8.5-9.5$ & 8.5 & 9.5 \\
\hline Inner row of pharyngeal teeth & 1 & 2 & 2 & 2 \\
\hline Pharyngeal Teeth & Robust & Robust & Robust & Weak \\
\hline Lachrymal manubrium & Wide & Narrow & Narrow & Narrow \\
\hline Ethmoid bone & Wide & Narrow & Wide & Narrow \\
\hline Kinethmoid bone & Narrow & Wide & Narrow & Narrow \\
\hline Caudal peduncle & $\begin{array}{l}\text { Low and elongated. } \\
A C L \text { is } \geq 2.1 \text { the } B L D\end{array}$ & $\begin{array}{l}\text { Low and elongated. } \\
A C L \text { is } \geq 2.1 \text { the BLD }\end{array}$ & $\begin{array}{l}\text { Short and high. } \\
A C L \text { is }<2 \text { the BLD }\end{array}$ & $\begin{array}{l}\text { Short and high. } \\
A C L \text { is }<2 \text { the BLD }\end{array}$ \\
\hline
\end{tabular}

PARATypes: Table 5. MNCN 286595-96: 2 specimens from Melloulou River, Moulouya Basin, Guercif, Mediterranean slope in Morocco (34.218035, -3.346732); 9/4/2007. Coll. Doadrio, I; Doadrio, I jr. and Perea, S. MNCN 290831: 1 specimen from Melloulou River, Moulouya Basin, Guercif, Mediterranean slope in Morocco (34.21526, -3.375668). 2/5/2015. Coll. Doadrio, I; Garzón, P; Perea, S and Yahyaoui, A. MNCN 290832: 1 specimen from Moulouya River, Moulouya Basin, Ghafoula, Mediterranean slope in Morocco (34.14534, -3.38847); 2/5/2015. Coll. Doadrio, I; Perea, S; Garzón, P and Yahyaoui, A. MNCN 290833-290834, 290836-290840: 7 specimens from Moulouya River, Moulouya Basin, Ghafoula, Mediterranean slope in Morocco (34.14534, -3.38847); 22/6/2015. Coll. Doadrio, I; Perea, S and Yahyaoui, A.

The holotype and a series of paratypes (12 specimens) have been deposited at the Fish Collection of the Museo Nacional de Ciencias Naturales, Madrid, Spain.

DIAGNOSIS: Differs from other known Luciobarbus species by the following combination of characters: $45-48$ scales along the lateral line $(\bar{x}=45.6$, median $=45)$, 6.5-8.5 ( $\bar{x}=7.4$, median=7.5) above lateral line, and 5.5 below lateral line. The last single ray of the dorsal fin is strongly ossified with the maximum width $6.2-9.2 \%$ (median=7.4) of its length. The last single dorsal fin ray is densely denticulated along its length,

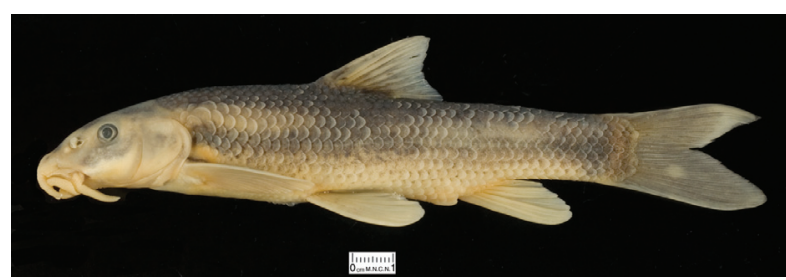

Fig. 7.- Holotype of Luciobarbus guercifensis from the Moulouya River, Ghafoula, Morocco. MNCN 290835. SL=139.4 mm.

Fig. 7.- Holotipo de Luciobarbus guercifensis del Río Moulouya, Ghafoula, Marruecos. MNCN 290835. SL=139,4 mm. and, in adults specimens, the number of denticulations exceeds 25 (Fig. 6). The ethmoid bone is wider than its length. Most specimens possess a single pharyngeal tooth in the inner row. The number of vertebrae is $39-41(\bar{x}=39.7, \mathrm{n}=11)$. The interorbital distance is 1.7 to 2.2 times (median=2) the eye diameter. The caudal peduncle is longer than the one seen in L. nasus and L. magniatlantis, with depth 2.1-2.6 times the length of the anal peduncle. The posterior segment (manubrium) of the lachrymal bone is short and high. Differences in diagnostic characters among analysed Luciobarbus populations are presented in Table 4.

DESCRIPTION: D III-V 8, A III 5, P I 15-16, V I 6, C 18; LL 45-48 ( $\bar{x}=45.6$, median $=45)$, RSA 6.5-8.5 $(\bar{x}=7.4$, median=7.5), RSB 5.5. Pharyngeal teeth in adults 4.3.1 or 4.2.1. GR 13-15 ( $\bar{x}=14.1$, median=14), VE 39-41 $(\bar{x}=39.7$, median $=40)$. Rarely reaches $200 \mathrm{~mm}$ SL. The body is elongated, relative to maximum body depth compared to other Luciobarbus species. Maximum body depth is $16-19 \%$ of SL. Head length $(\bar{x}=28.5 \mathrm{~mm})$ is $25-27 \%$ of SL and greater than body depth $(\bar{x}=20.1 \mathrm{~mm})$. The skull is wide, with the ethmoid bone width greater than its length. The interorbital distance is 1.7 to 2.2 times eye diameter. Infraorbital bones are narrow and the lachrymal bone is shorter than in Oum er Rbia population as consequence of a shorter manubrium. The height of the manubrium is $20-23 \%$ the lachrymal length. Thick lips and barbels display granular appearance. The first pair of barbels is short and located at the anterior extreme of the mouth, reaching the insertion of the second pair of barbels. The second pair of barbels is thick and reaches the posterior edge of the eye. The anterior barbel is 23.2-29.7\%, and the second 34.6-38.6\%, of HL. The snout is prominent, with preorbital length $10-12.6 \%$ of SL. The preorbital length $(\bar{x}=13.6 \mathrm{~mm})$ is larger 
Table 5.- Morphometric and meristic measurement of the holotype and paratypes of Luciobarbus guercifensis. Acronyms are defined in the Material and Methods section.

Tabla 5.- Medidas morfométricas y merísticas del holotipo y paratipos de Luciobarbus guercifensis. Los acrónimos están definidos en la sección de Material y Métodos.

\begin{tabular}{|c|c|c|c|c|}
\hline \multirow[b]{2}{*}{$\begin{array}{l}\text { Morphometric } \\
\text { variable }\end{array}$} & \multirow{2}{*}{$\begin{array}{c}\text { Holotype } \\
\text { MNCN 290835 } \\
\begin{array}{c}\text { Measurements } \\
(\mathrm{mm})\end{array}\end{array}$} & \multicolumn{3}{|c|}{ Paratypes $n=11$} \\
\hline & & Range & Mean & $\begin{array}{l}\text { Standard } \\
\text { Deviation }\end{array}$ \\
\hline SL & 139.4 & 75.7-149.4 & 109.4 & 23.5 \\
\hline PrDD & 66.7 & $37.1-70.3$ & 52.5 & 10.4 \\
\hline PrPD & 35.2 & $20.1-38.2$ & 28.3 & 5.7 \\
\hline PrVD & 61.2 & $35.4-69.8$ & 50.5 & 10.8 \\
\hline PrAD & 97.7 & $49.7-107.8$ & 75.9 & 18.4 \\
\hline PVL & 30.4 & $15.4-34.3$ & 24.3 & 5.6 \\
\hline CPL & 58.1 & $30.9-60.6$ & 44.6 & 9.5 \\
\hline APL & 32.8 & $19.1-34.8$ & 26.3 & 4.9 \\
\hline $\mathrm{BD}$ & 26 & $12.4-28.1$ & 19.5 & 4.9 \\
\hline BLD & 14.9 & $7.8-16.2$ & 11.5 & 2.7 \\
\hline $\mathrm{HL}$ & 35 & $20.5-37.8$ & 27.8 & 5.6 \\
\hline PrOL & 17.3 & $8.1-18.8$ & 12.6 & 3.2 \\
\hline ED & 5 & $3-5.2$ & 4 & 0.7 \\
\hline $\mathrm{PsOL}$ & 15.4 & $8.7-16$ & 12.1 & 2.3 \\
\hline IOW & 10.5 & $5.1-11.3$ & 7.9 & 1.9 \\
\hline $\mathrm{B} 1 \mathrm{~L}$ & 9.7 & $4.7-11$ & 7.4 & 2 \\
\hline $\mathrm{B} 2 \mathrm{~L}$ & 12.8 & 7.1-13.7 & 10.2 & 2.1 \\
\hline PFL & 30 & 16.8-33.3 & 24.1 & 4.9 \\
\hline VFL & 27.3 & $16.8-31$ & 22.7 & 4.5 \\
\hline DFL & 17.1 & $9.2-17.7$ & 13.4 & 2.8 \\
\hline DFH & 27.2 & $15.7-28.5$ & 22 & 4 \\
\hline AFL & 11 & $5.8-12.1$ & 8.6 & 2.0 \\
\hline $\mathrm{AFH}$ & 26.4 & $16.3-28.5$ & 22.1 & 3.9 \\
\hline CFL & 32.5 & $16.5-34.1$ & 26.1 & 5.3 \\
\hline LL & 45 & $45-48$ & 45.7 & 0.9 \\
\hline RSA & 7.5 & $5.5-8.5$ & 7.4 & 0.5 \\
\hline RSB & 5.5 & 5.5 & 5.5 & - \\
\hline
\end{tabular}

than the postorbital length $(\bar{x}=12 \mathrm{~mm})$. The dorsal fin is posterior on the body but slightly more anterior than in other rheophilic barbs, with the predorsal distance being $46.2-50 \%$ of SL. The profile of the dorsal fin is concave, with the last single ray ossified with more than 25 denticulations (Fig. 5). In males, the anal fin is longer than the one seen in L. nasus and L. magniatlantis with its height $76-92 \%$ of APL. The caudal peduncle is less deep than in L. magniatlantis and L. nasus, with a height 9.9-10.9\% of SL. The length of the anal caudal peduncle is 2.1 to 2.6 times its height. In males, the pectoral and ventral fins are long with pectoral fins usually reaching the origin of the ventral fins. Males exhibited numerous nuptial tubercles of equal size distributed over the body and fins. The caudal fin length is $16.6-27.3 \%$ of SL. Morphometric and meristic measurements for the holotype and paratypes of Luciobarbus guercifensis are presented in Table 5. The colouration of L. guercifensis is silver-yellowish with a paler ventral area (Fig. 2).

DISTRIBUTION: This species is endemic to Moulouya basin, inhabiting Moulouya and Melloul rivers in riffle areas near to the Guercif village (Fig. 1).

ETYMOLOGY: The species name 'guercifensis' was selected, as because the species is mainly distributed around the Guercif village in Morocco.

COMMON NAME: We propose the English common name 'Guercif barbel' for this new species.

HABITAT AND BIOLOGY: The species inhabits large rivers, mainly in mid-stream, usually in riffle areas. No information exists on the spawning period or reproductive behaviour.

CONSERVATION: Currently, Luciobarbus guercifensis is a rare species that has been found in few places, localized in riffle areas. These riffle areas are becoming scarce in Moulouya River as a consequence of increasing crop irrigation at its headwaters. The water taken for irrigation, as well as the impact of fertilizers and pesticides on water quality in the lower courses has likely been the primary cause of the recent decline of this population. No quantification of the decline in numbers is available. We suggest that this species should be included in the IUCN category of Endangered.

GENETICS: Uncorrected- $p$ distance of mitochondrial cytb gene between Luciobarbus guercifensis and the other analysed species are presented in Table 3. L. guercifensis shows 63 diagnostic positions in the cytb gene with respect to other rheophilic barbels.

Luciobarbus zayanensis sp. nov. Doadrio, Casal-López \& Yahyaoui

http://1sid:zoobank.org:act:7A79DAD4-B60A-43F9-8BF6617B34670E64

Holotype: Fig. 8, Table 6. MNCN 279706, male, 113 mm (SL); Chbouka River, Oum er Rbia Basin, El Herri (Elhri), Atlantic slope in Morocco (32.859510, -5.621355) (Fig. 1); 27/3/2013. 872 ATSL. Coll. Doadrio, I; Yahyaoui, A; Garzón, P and Perea, S.

PARATYPes: Table 6. MNCN 55094 one specimen from the Douna River, Oum er Rbia Basin, El Khemis, Atlantic slope in Morocco (32.750866, -5.541695); 7/5/1988. Coll. Doadrio, I; Merino, M; Cubo J and González, JL. MNCN 208115-208116: 2 specimens from Serrou River, Oum er Rbia Basin, El Herri, Atlantic slope in Morocco (32.827621, -5.615255). 27/4/2000. Coll. Doadrio, I; Garzón, P; Doadrio, A and Doadrio, I Jr. MNCN 54987-55000: 14 specimens from the Arba River, Oum er Rbia Basin, Ksiba, Atlantic slope in Morocco (32.566810, -6.017450). 8/5/1988. Coll. Doadrio, I; Merino, M; Cubo J and González, J.L. MNCN 208168-208169, 


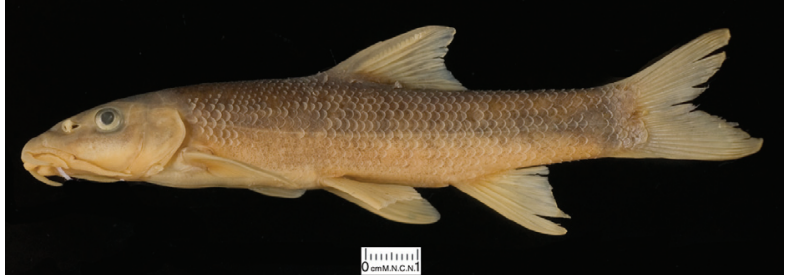

Fig. 8.- Holotype of Luciobarbus zayanensis from the Chbouka River, Oum er Rbia Basin. El Herri, Morocco. MNCN 279706. $\mathrm{SL}=113 \mathrm{~mm}$.

Fig. 8.- Holotipo de Luciobarbus zayanensis del Río Chbouka, Cuenca del Oum er Rbia. El Herri, Marruecos. MNCN 279706. $\mathrm{SL}=113 \mathrm{~mm}$.

Table 6.- Morphometric and meristic measurement of the holotype and paratypes of Luciobarbus zayanensis. Acronyms are defined in the Material and Methods section.

Tabla 6.- Medidas morfométricas y merísticas del holotipo y paratipos de Luciobarbus zayanensis. Los acrónimos están definidos en la sección de Material y Métodos.

\begin{tabular}{|c|c|c|c|c|}
\hline \multirow[b]{2}{*}{$\begin{array}{l}\text { Morphometric } \\
\text { measurement }\end{array}$} & \multirow{2}{*}{$\begin{array}{c}\text { Holotype } \\
\text { MNCN 279706 } \\
\begin{array}{c}\text { Measurements } \\
(\mathrm{mm})\end{array}\end{array}$} & \multicolumn{3}{|c|}{ Paratypes $n=32$} \\
\hline & & Range & Mean & $\begin{array}{l}\text { Standard } \\
\text { Deviation }\end{array}$ \\
\hline SL & 113 & $64.5-178.0$ & 118.2 & 25.1 \\
\hline PrDD & 56.7 & 33.3-92.5 & 59.5 & 12.7 \\
\hline PrPD & 30 & $17.9-41.5$ & 29.7 & 5.3 \\
\hline PrVD & 54.7 & 33.3-79.4 & 55.1 & 10.5 \\
\hline PrAD & 78.4 & $44.6-121.6$ & 81.7 & 17.2 \\
\hline PVL & 26.4 & $13.6-42.3$ & 27.1 & 6.6 \\
\hline CPL & 43.7 & $25.4-76.3$ & 48.5 & 11.3 \\
\hline APL & 28.3 & $16.0-45.2$ & 29.8 & 6.3 \\
\hline $\mathrm{BD}$ & 20.8 & $12.0-43.4$ & 25.7 & 7.0 \\
\hline BLD & 12.3 & $6.1-20.6$ & 13.3 & 3.0 \\
\hline $\mathrm{HL}$ & 28.9 & $17.4-43.4$ & 29.6 & 5.8 \\
\hline PrOL & 14.9 & $7.8-20.5$ & 13.8 & 2.8 \\
\hline ED & 4.6 & $3.5-6.3$ & 4.7 & 0.6 \\
\hline PsOL & 12 & $8.8-17.3$ & 12.8 & 1.9 \\
\hline IOW & 7.1 & $4.1-12.5$ & 7.8 & 1.8 \\
\hline B1L & 8.1 & $4.8-8.0$ & 6.5 & 1.1 \\
\hline B2L & 10.5 & $6.2-11.8$ & 9.4 & 1.6 \\
\hline PFL & 23.4 & $15.1-33.4$ & 24.1 & 4.1 \\
\hline VFL & 22.1 & $14.0-30.6$ & 22.1 & 3.5 \\
\hline DFL & 15.6 & $8.0-23.0$ & 14.7 & 3.1 \\
\hline DFH & 25 & $14.7-32.7$ & 22.8 & 4.1 \\
\hline AFL & 8.3 & $5.3-14.1$ & 9.2 & 2.1 \\
\hline $\mathrm{AFH}$ & 21 & $11.3-29.2$ & 20.2 & 4.2 \\
\hline CFL & 27.1 & 15.1-37.5 & 25.5 & 4.9 \\
\hline LL & 51 & $49.0-53.0$ & 51.1 & 1.2 \\
\hline RSA & 9.5 & $8.5-9.5$ & 9.3 & 0.4 \\
\hline RSB & 5.5 & $5.5-7.5$ & 6.6 & 0.6 \\
\hline
\end{tabular}

MNCN 71972-71978: 9 specimens from the Oum er Rbia River, El Borj, Atlantic slope in Morocco Morocco (33.015769, -5.629534). 18/4/1991. Coll. Doadrio, I; Perdices, A and Cubo, J. MNCN 279704-279705, MNCN 279707, MNCN 280083, MNCN 279695279696: 6 specimens from the Chbouka River, Oum er Rbia Basin, El Herri, Atlantic slope in Morocco (32.859510, -5.62135527/3/2013. 27/3/2013. Coll. Doadrio, I; Yahyaoui, A; Garzón, P; and Perea, S.

Holotype and a series of paratypes (33 specimens) have been deposited at the Fish Collection of the Museo Nacional de Ciencias Naturales, Madrid, Spain.

DIAGNOSIS: Differs from other known species of Luciobarbus by the following combination of characters: $49-53$ scales along the lateral line $(\bar{x}=51$, median $=51) ; 8.5-9.5$ scales $(\bar{x}=9.3$, median $=9.5)$ above lateral line and 5.5-7.5 ( $\bar{x}=6.5$, median $=6.5)$ below lateral line. The last single ray of the dorsal fin is strongly ossified with a maximum width of $12-14.5 \%$ (median $=13.9 \%$ ) of its length. The last single dorsal fin ray is densely denticulate along its length and, in adults, the number of denticulations is smaller than 23 (Fig. 5). The skull is narrow, with the width of the ethmoid bone smaller than its length. The inter-orbital distance is 1.2 to 1.9 times (median=1.6) eye diameter. The pharyngeal teeth formula in adults is 4.3.2. The number of vertebrae is $41-43(\bar{x}=42, n=10)$. Large deep caudal peduncle $2.1-2.6 \%$ of APL. Lachrymal bone with narrow posterior segment (manubrium). Differences in diagnostic characters among analysed Luciobarbus populations are presented in Table 4.

DESCRIPTION: D III-V 8, A III 5, P I 15-16, V I 6, C 18; LL 49-53 ( $\bar{x}=51$, median $=51)$, RSA 8.5-9.5 $(\bar{x}=9.3$, median=9.5), RSB 5.5-7.5 ( $\bar{x}=6.5$, median=6.5). Pharyngeal teeth in adults 4.3.2. GR 13-16 ( $\bar{x}=14.5$, median=14.5), VE 41-43 ( $\bar{x}=42, \mathrm{n}=10)$. Similarly to other rheophilic Luciobarbus, it is a small-sized species, rarely reaching $200 \mathrm{~mm}$ SL. Females are larger $(\bar{x}=128.6 \mathrm{~mm})$ than males $(\bar{x}=112.9 \mathrm{~mm})$. The body is elongated with maximum body depth $18-24 \%$ of SL in males and $21-24 \%$ in females. The head is typically sharp and narrow. The inter-orbital distance is 1.2 to 1.9 times the eye diameter in males and 1.4 to 1.9 times in females. The skull is narrow, with the ethmoid bone longer than wide. The frontal bones are narrower relative to other rheophilic barbs, notably in the anterior part. Infraorbital bones are narrow, and the lachrymal bone is longer than in other rheophilic barbs and possesses a long manubrium. The height of the manubrium is $10-13 \%$ the lachrymal bone length. The kinethmoid bone is more robust than the one found in other rheophilic barbs. Thick lips and barbels with granular appearance. The first pair of barbels is short and positioned at the anterior extreme of the mouth, reaching the insertion of the second pair of barbels. The second pair of barbels is thick and reaches the posterior edge of the eye. The anterior barbel length is $20.1-29.9 \%$, and the second $29.7-39.5 \%$ 
of HL. The snout is prominent, with preorbital length $10.9-12.1 \%$ of SL in females and 10.6-13.2 in males. The preorbital length $(\bar{x}=14.8 \mathrm{~mm}$ in females and $\bar{x}=13.5 \mathrm{~mm}$ in males) is greater than the postorbital length ( $\bar{x}=13.5 \mathrm{~mm}$ in females and $\bar{x}=12.3 \mathrm{~mm}$ in males). The pectoral and ventral fins are larger in males than in females. The pectoral fin length is $76-83 \%$ $(\bar{x}=80 \%)$ of HL in females and $72-90 \%(\bar{x}=83 \%)$ of HL in males. The ventral fin length is $65.5-74 \%$ $(\bar{x}=70 \%)$ of HL in females and $65.5-85 \%(\bar{x}=78 \%)$ of HL in males. The dorsal fin is located posteriorly on the body, with the predorsal distance being 48.9$52.5 \%$ of SL in females and $48.5-52.5 \%$ in males. The profile of the dorsal fin is concave, with the last single ray of the dorsal fin ossified with few and strong denticulations (Fig. 5). The caudal peduncle is elongated, and the least body depth is $11-11.9 \% \mathrm{SL}$ in females and $9.5-11.8 \% \mathrm{SL}$ in males. The length of the anal caudal peduncle is 2.1 to 2.3 times the height of the anal peduncle in females and 2.1-2.6 times in males. Males exhibited numerous equal-sized nuptial tubercles distributed over the body and fins. The caudal fin length is $20-23 \%$ of SL in females and $18.4-24.5 \%$ of SL in males. Morphometric and meristic measurements for the holotype and paratypes of Luciobarbus zayanensis are represented in Table 6 . The coloration of $L$. zayanensis is brownish with a paler ventral area and some black spots along the body (Fig. 2).

DISTRIBUTION: This species is endemic to Oum er Rbia basin, inhabiting riffle areas with clear waters in the Atlas Mountains (Fig. 1).

ETYMOLOGY: The species name 'zayanensis' has been selected because it is mainly distributed around Middle Atlas region, in the area inhabited by the Zayanes shepherds.

COMMON NAME: We suggest the English common name 'Zayan barbel' for this new species.

HABITAT AND BIOLOGY: The species inhabits riffle areas in headwaters of large rivers. Spawning takes places from late April to early May.

CONSERVATION: The habitat of $L$. zayanensis is being transformed by dam and reservoir constructions and by increased pollution linked to agriculture and urban development for tourism. The population of L. zayanensis is in decline, therefore we suggest that this species should be included in the IUCN category of Vulnerable.

GENETICS: Uncorrected- $p$ distances of mitochondrial gene cytb between $L$. zayanensis and the other analysed species are presented in Table 3. Luciobarbus zayanensis shows 5 diagnostic positions in the cytb gene.

\section{Acknowledgments}

Many persons have participated in the field sampling trips. We warmly thank J. Cubo, M. Merino, J. L. González, P. Garzón, I. Doadrio Jr., A. Doadrio, A. Perdices, Y. Bernat, and S. El Gharbi. We would also like to thank L. Alcaraz, for laboratory work, G. Solís, curator of ichthyological collection, and I. Rey and B. Álvarez, curators of the DNA collection of the National Museum of the Natural Sciences (MNCN-CSIC). We also thank C. Parejo and M. Pérez for her technical assistance in nondestructive techniques with the computerized tomography scan at the MNCN-CSIC. James Maclaine, curator of Natural History Museum, was always willing to help in the study of the L. nasus type series. We are grateful also to P. Fernández for format editing, and the Lucidus Consultancy for English editing of this article. This project was funded by Ministère de l'Enseignement supérieur from Morocco to the Project NoPPR/2015/2 Impact des changements climatiques sur la diversité génétique des poissons des eaux douces du Maroc. Permission for fish collection was provided by Eaux et Foret Commission of Morocco.

\section{References}

Akaike, H., 1973. Information theory and an extension of the Maximum Likelihood principle. In: B. N. Petrov \& F. Csaki (eds.). Proceedings of the second International Symposium on Information Theory. Akademini Kiado. Budapest: 267-281.

Almaça, C., 1970. Sur les barbeaux (genre et sous-genre Barbus) de l'Afrique du Nord. Bulletin du Muséum National d'Histoire Naturelle, 42: 141-158.

Almaça, C., 1971. Sur la spéciation des barbeaux nordafricains. Bulletin du Muséum National d'Histoire Naturelle, $2^{\text {ème }}$ série, 42(5): 853-856.

Banarescu, P., 1999. The freshwater Fishes of Europe. Vol 5/II, Part II. Aula. Wiebelsheim.

Burnaby, T. P., 1966. Growth-invariant discriminant functions and generalized distances. Biometrics, 22: 96-110. http://dx.doi.org/10.2307/2528217

Borkenhagen, K. \& Krupp, F., 2013. Taxonomic revision of the genus Carasobarbus Karaman, 1971 (Actinopterygii, Cyprinidae). ZooKeys, 339: 1-53. http://dx.doi. org/10.3897/zookeys.339.4903

Casal-López, M., Perea, S., Yahyaoui, A. \& Doadrio, I., 2015. Taxonomic review of the genus Luciobarbus Heckel, 1843 (Actinopterygii, Cyprinidae) from Northwestern Morocco with the description of three new species. Graellsia, 71(2): e027. http://dx.doi.org/ 10.3989/graellsia.2015.v71.135

Doadrio, I., 1990. Phylogenetics relationships and classification of western paleartic species of the genus Barbus (Osteichthyes, Cyprinidae). Aquatic Living Resources, 3: 265-282.

Doadrio, I., 1994. Freshwater fish fauna of North Africa and its biogeography. Annals of the Royal Central African Museum (Zoology), 275: 21-34.

Doadrio, I. \& Carmona, J. A. 2003. A new species of the genus Chondrostoma Agassiz, 1832 (Actinopterygii, Cyprinidae) from the Iberian Peninsula. Graellsia, 59(1): 29-36. http://dx.doi.org/10.3989/graellsia.2003. v59.i1.221 
Doadrio, I., \& Carmona, J. A., 2006. Phylogenetic overview of the genus Squalius (Actinopterygii, Cyprinidae) in the Iberian Peninsula, with description of two new species. Cybium, 30(3): 199-214.

Doadrio, I. \& Elvira, B., 2007. A new species of the genus Achondrostoma Robalo, Almada, Levy \& Doadrio, 2007 (Actinopterygii, Cyprinidae) from western Spain. Graellsia, 63(2): 295-304. http://dx.doi.org/10.3989/ graellsia.2007.v63.i2.96

Doadrio, I. \& Madeira, M. J., 2004. A new species of the genus Gobio Cuvier 1816 (Actynopterigii, Cyprinidae) from the Iberian Peninsula and south of France. Graellsia, 60(1): 107-116. http://dx.doi.org/10.3989/graellsia.2004. v60.il.197

Doadrio, I., Perea, S., Garzón-Heydt, P. \& González, J. L., 2011. Ictiofauna Continental Española. Bases para su seguimiento. Dirección General Medio Natural y Política Forestal, Ministerio de Medio Ambiente y Medio Rural y Marino. Madrid. 610 pp.

Domínguez-Domínguez, O., Pompa-Domínguez, A. \& Doadrio, I., 2007. A new species of the genus Yuriria Jordan \& Evermann, 1896 (Actinopterygii, Cyprinidae) from the Ameca basin of the Central Mexican Plateau. Graellsia, 63(2): 259-271. http://dx.doi.org/10.3989/ graellsia.2007.v63.i2.93

Domínguez-Domínguez, O., Pérez-Rodríguez, R., EscaleraVázquez, L. H. \& Doadrio, I., 2009. Two new species of the genus Notropis Rafinesque, 1817 (Actinopterygii, Cyprinidae) from the Lerma River Basin in Central Mexico. Hidrobiológica, 19(2): 159-172.

Estève, R., 1947. Étude biométrique des barbeaux marocains. Bulletin du Muséum National d'Histoire Naturelle, 3: $265-270$.

Günther, A., 1874. Notice of some new species of fishes from Morocco. Annals and Magazine of Natural History, Series 4, 13(75): 230-232. http://dx.doi.org/10.1080/ 00222937408680848

Hammer, Ø., Harper, D. A. T. \& Ryan, D., 2001. PAST: Paleontological Statistics Software Package for Education and Data Analysis. Paleontological Electronica, 41(1): 9 pp.

Kottelat, M. \& Freyhof, J., 2007. Handbook of European freshwater fishes. Cornol. Berlin. 646 pp.

Lévêque, C. \& Daget, J., 1984. Cyprinidae. In: J. Daget, J. P. Gosse \& D. F. E. Thys van den Audenaerde (eds.). Checklist of the Freshwater Fishes of Africa (CLOFFA)/ Catalogue des Poissons d'eau douce d'Afrique, vol. 1. MRAC \& ORSTOM. Tongeren: 217-342.

Levin, B. A., Freyhof, J., Lajbner, Z., Perea, S., Abdoli, A., Gaffaroğlu, M., Özulug, M., Rubenyan, H. R., Salnikov, V. B. \& Doadrio, I., 2012. Phylogenetic relationships of the algae scraping cyprinid genus Capoeta (Teleostei: Cyprinidae). Molecular Phylogenetics and Evolution, 62(1): 542-549. http://dx.doi.org/10.1016/j. ympev.2011.09.004
Machordom, A. \& Doadrio, I., 2001a. Evolutionary history and speciation modes in the cyprinid genus Barbus. Proceedings of the Royal Society of London. Series B: Biological Sciences, 268(1473): 1297-1306. http:// dx.doi.org/10.1098/rspb.2001.1654

Machordom, A. \& Doadrio, I., 2001b. Evidence of a Cenozoic Betic-Kabilian connection based on freshwater fish phylogeography (Luciobarbus, Cyprinidae). Molecular Phylogenetics and Evolution, 18(2): 252-263. http://dx.doi.org/10.1006/mpev.2000.0876

Machordom, A., Doadrio, I. \& Berrebi, P., 1995. Phylogeny and evolution of the genus Barbus in the Iberian Peninsula as revealed by allozyme electrophoresis. Journal of Fish Biology, 47(2): 211-236. http://dx.doi. org/10.1111/j.1095-8649.1995.tb01890.x

Pellegrin, J., 1919. Sur deux Cyprinidés nouveaux du Maroc appartenant au genre Barbus. Bulletin de la Société Zoologique de France, 44: 31-35.

Pellegrin, J., 1939. Les barbeaux de l'Afrique du Nord Française: description d'une espèce nouvelle. Bulletin de la Société des Sciences Naturelles du Maroc, 19(1): 1-10.

Posada, D., 2008. jModelTest: Phylogenetic Model Averaging. Molecular Biology and Evolution, 25(7): 1253-1256. http://dx.doi.org/10.1093/molbev/msn083

Robalo, J. I., Almada, V. C., Sousa Santos, C., Moreira, M. I. \& Doadrio, I., 2005. New species of the genus Chondrostoma Agassiz, 1832 (Actinopterygii, Cyprinidae) from western Portugal. Graellsia, 61(1): 15-28. http://dx.doi.org/10.3989/graellsia.2005.v61.i1.3

Rohlf, F. J. \& Bookstein, F. L., 1987. A comment on shearing as a method for "size correction". Systematic Zoology, 36(4): 356-367. http://dx.doi.org/10.2307/2413400

Ronquist, F., Teslenko, M., van der Mark, P., Ayres, D. L., Darling, A., Höhna, S., Larget, B., Liu, L., Suchard, M. A. \& Huelsenbeck, J. P., 2012. MrBayes 3.2: Efficient Bayesian Phylogenetic Inference and Model Choise Across Large Model Space. Systematic Biology, 61(3): 539-542. http://dx.doi.org/10.1093/sysbio/sys029

Tamura, K., Stecher, G., Peterson, D., Filipski, A. \& Kumar, S., 2013. MEGA6: Molecular Evolutionary Genetics Analysis (MEGA) Software version 6.0. Molecular Biology and Evolution, 24(8): 1596-1599. http://dx.doi. org $/ 10.1093 / \mathrm{molbev} / \mathrm{mst} 197$

Yang, L., Sado, T., Vincent Hirt, M., Pasco-Viel, E., Arunachalam, M., Li, J., Wang, X., Freyhof, J., Saitoh, K., Simons, A. M., Miya, M., He, S. \& Mayden, R. L., 2015. Phylogeny and polyploidy: resolving the classification of cyprinine fishes (Teleostei: Cypriniformes). Molecular Phylogenetics and Evolution, 85: 97-116. http://dx.doi.org/10.1016/j.ympev.2015.01.014

Zardoya, R. \& Doadrio, I., 1999. Molecular evidence on the evolutionary and biogeographical patterns of European cyprinids. Journal of Molecular Evolution, 49(2): 227-237. http://dx.doi.org/10.1007/PL00006545 
Appendix 1.- Kruskal-Wallis test and Non-parametric Mann-Whitney's pairwise post hoc comparisons for all populations. Values of Kruskal-Wallis test $(H)$ below variables. Values of MannWhitney test are below the diagonal. The median is the diagonal of each variable. Significant differences $p<0.05\left(^{*}\right) ; p<0.01\left(^{(*}\right)$. Acronyms are defined in the Material and Methods section.

Apéndice 1.- Test de Kruskal-Wallis y comparaciones post hoc no paramétricas de MannWhitney para todas la poblaciones. Los valores del test de Kruskal-Wallis $(\mathrm{H})$ aparecen debajo de las variables. Los valores del test de Mann-Whitney están debajo de la diagonal. La mediana es la diagonal de cada variable. Diferencias significativas $p<0.05\left(^{*}\right) ; p<0.01\left(^{* *}\right)$. Los acrónimos están definidos en la sección de Material y Métodos.

\begin{tabular}{|c|c|c|c|c|}
\hline Variables & Populations & $\begin{array}{l}\text { Tensift } \\
(n=14)\end{array}$ & $\begin{array}{c}\text { Oum er Rbia } \\
(n=21)\end{array}$ & $\begin{array}{c}\text { Moulouya } \\
(n=12)\end{array}$ \\
\hline \multirow[t]{3}{*}{$\mathrm{SL}(\mathrm{H}=0.502)$} & Tensift & 108.6 & & \\
\hline & Oum er Rbia & 0.449 & 112.9 & \\
\hline & Moulouya & 0.763 & 0.968 & 109.2 \\
\hline \multirow[t]{3}{*}{$\operatorname{PrDD}\left(H=14.63^{\star \star}\right)$} & Tensift & $52.9 / 0.49$ & & \\
\hline & Oum er Rbia & 0.88 & $55.8 / 0.5$ & \\
\hline & Moulouya & $<0.0001^{\star *}$ & $<0.0001^{\star \star}$ & $53.3 / 0.48$ \\
\hline \multirow[t]{3}{*}{$\operatorname{PrPD}\left(\mathrm{H}=16.54^{\star \star}\right)$} & Tensift & $25.2 / 0.24$ & & \\
\hline & Oum er Rbia & $0.005^{\star *}$ & $29.4 / 0.26$ & \\
\hline & Moulouya & $<0.0001^{\star \star}$ & 0.052 & $28.7 / 0.26$ \\
\hline \multirow[t]{3}{*}{$\operatorname{PrVD}(\mathrm{H}=4.197)$} & Tensift & $50.2 / 0.46$ & & \\
\hline & Oum er Rbia & 0.96 & $54.7 / 0.47$ & \\
\hline & Moulouya & 0.095 & 0.057 & $52 / 0.46$ \\
\hline \multirow[t]{3}{*}{$\operatorname{PrAD}(\mathrm{H}=1.556)$} & Tensift & $73.4 / 0.68$ & & \\
\hline & Oum er Rbia & 0.827 & $78.4 / 0.68$ & \\
\hline & Moulouya & 0.529 & 0.177 & $77.2 / 0.7$ \\
\hline \multirow[t]{3}{*}{$\operatorname{PVL}\left(\mathrm{H}=13.73^{\star \star}\right)$} & Tensift & $24.9 / 0.24$ & & \\
\hline & Oum er Rbia & $0.002^{\star *}$ & $24.9 / 0.22$ & \\
\hline & Moulouya & $0.0005^{\star \star}$ & 0.8427 & $25 / 0.22$ \\
\hline \multirow[t]{3}{*}{$\mathrm{CPL}(\mathrm{H}=1.89)$} & Tensift & $42.7 / 0.41$ & & \\
\hline & Oum er Rbia & 0.372 & $44.2 / 0.4$ & \\
\hline & Moulouya & 0.978 & 0.177 & $44.3 / 0.41$ \\
\hline \multirow[t]{3}{*}{ APL $\left(H=17.8^{\star \star}\right)$} & Tensift & $25.3 / 0.24$ & & \\
\hline & Oum er Rbia & $<0.0001^{\star \star}$ & $28.3 / 0.25$ & \\
\hline & Moulouya & 0.019 & 0.06 & $26 / 0.24$ \\
\hline \multirow[t]{3}{*}{$\mathrm{BD}\left(\mathrm{H}=24.63^{\star \star}\right)$} & Tensift & $22.4 / 0.21$ & & \\
\hline & Oum er Rbia & 0.259 & $23.4 / 0.2$ & \\
\hline & Moulouya & $<0.0001^{\star \star}$ & $<0.0001^{\star \star}$ & $19.7 / 0.18$ \\
\hline \multirow[t]{3}{*}{$\operatorname{BLD}\left(\mathrm{H}=34.48^{\star \star}\right)$} & Tensift & $12.8 / 0.12$ & & \\
\hline & Oum er Rbia & $<0.0001^{\star *}$ & $12.5 / 0.11$ & \\
\hline & Moulouya & $<0.0001^{\star \star}$ & $<0.0001^{\star *}$ & $11.7 / 0.11$ \\
\hline \multirow[t]{3}{*}{$\mathrm{HL}\left(\mathrm{H}=29.07^{\star \star}\right)$} & Tensift & $25.1 / 0.24$ & & \\
\hline & Oum er Rbia & $<0.0001^{\star *}$ & $28.9 / 0.25$ & \\
\hline & Moulouya & $<0.0001^{\star *}$ & 0.234 & $28.5 / 0.25$ \\
\hline \multirow[t]{3}{*}{$\operatorname{PrOL}(\mathrm{H}=2.33)$} & Tensift & $12.7 / 0.12$ & & \\
\hline & Oum er Rbia & 0.578 & $13.5 / 0.12$ & \\
\hline & Moulouya & 0.106 & 0.365 & $13.6 / 0.11$ \\
\hline \multirow[t]{3}{*}{$\mathrm{PsOL}\left(\mathrm{H}=22.8^{\star \star}\right)$} & Tensift & $11.1 / 0.1$ & & \\
\hline & Oum er Rbia & $<0.0001^{\star *}$ & $12.3 / 0.11$ & \\
\hline & Moulouya & $0.0002^{\star *}$ & 8427 & $12 / 0.11$ \\
\hline \multirow[t]{3}{*}{$\operatorname{ED}\left(\mathrm{H}=30.41^{\star \star}\right)$} & Tensift & $4.7 / 0.04$ & & \\
\hline & Oum er Rbia & 0.002 & $4.6 / 0.04$ & \\
\hline & Moulouya & $<0.0001^{\star *}$ & $<0.0001^{* *}$ & $4.2 / 0.04$ \\
\hline
\end{tabular}


Appendix 1.- (Continued)

\begin{tabular}{|c|c|c|c|c|}
\hline Variables & Populations & $\begin{array}{l}\text { Tensift } \\
(n=14)\end{array}$ & $\begin{array}{c}\text { Oum er Rbia } \\
(n=21)\end{array}$ & $\begin{array}{c}\text { Moulouya } \\
(n=12)\end{array}$ \\
\hline \multirow[t]{3}{*}{ PFL $\left(H=28.05^{\star \star}\right)$} & Tensift & $20.9 / 0.2$ & & \\
\hline & Oum er Rbia & $0.0001^{\star *}$ & $24.2 / 0.21$ & \\
\hline & Moulouya & $<0.0001^{\star \star}$ & $0.0009^{\star \star}$ & $24.5 / 0.22$ \\
\hline \multirow[t]{3}{*}{$\operatorname{VFL}\left(\mathrm{H}=24.74^{\star \star}\right)$} & Tensift & $19.4 / 0.18$ & & \\
\hline & Oum er Rbia & $0.0009^{\star \star}$ & $22.2 / 0.2$ & \\
\hline & Moulouya & $<0.0001^{* *}$ & $0.001^{\star *}$ & $23.5 / 0.2$ \\
\hline \multirow[t]{3}{*}{ DFL $(H=3.7)$} & Tensift & $13.8 / 0.12$ & & \\
\hline & Oum er Rbia & 0.699 & $14.8 / 0.13$ & \\
\hline & Moulouya & 0.132 & 0.074 & $13.6 / 0.12$ \\
\hline \multirow[t]{3}{*}{$\operatorname{DFH}\left(H=26.43^{\star \star}\right)$} & Tensift & $19.6 / 0.18$ & & \\
\hline & Oum er Rbia & $<0.0001^{* *}$ & $23.1 / 0.2$ & \\
\hline & Moulouya & $<0.0001^{\star *}$ & 0.7812 & $21.9 / 0.2$ \\
\hline \multirow[t]{3}{*}{ AFL $(\mathrm{H}=1.27)$} & Tensift & 8.3/0.08 & & \\
\hline & Oum er Rbia & 0.88 & $9.1 / 0.08$ & \\
\hline & Moulouya & 0.218 & 0.451 & $8.9 / 0.08$ \\
\hline \multirow[t]{3}{*}{ AFH $\left(H=25.74^{\star \star}\right)$} & Tensift & $17.6 / 0.16$ & & \\
\hline & Oum er Rbia & 0.1623 & 19.9/0.17 & \\
\hline & Moulouya & $<0.0001^{\star *}$ & $<0.0001^{\star \star}$ & $22.4 / 0.2$ \\
\hline \multirow[t]{3}{*}{ IOW $\left(\mathrm{H}=32.72^{\star \star}\right)$} & Tensift & 7.9/0.07 & & \\
\hline & Oum er Rbia & $<0.0001^{* *}$ & $7.1 / 0.06$ & \\
\hline & Moulouya & 0.132 & $<0.0001^{\star \star}$ & $8.1 / 0.07$ \\
\hline \multirow[t]{3}{*}{$\operatorname{LL}\left(\mathrm{H}=37.66^{\star \star}\right)$} & Tensift & 49 & & \\
\hline & Oum er Rbia & $<0.0001^{\star *}$ & 51 & \\
\hline & Moulouya & $<0.0001^{* *}$ & $<0.0001^{\star *}$ & 45 \\
\hline \multirow[t]{3}{*}{$\operatorname{RSA}\left(\mathrm{H}=40.5^{\star \star}\right)$} & Tensift & 8.5 & & \\
\hline & Oum er Rbia & $<0.0001^{\star *}$ & 9.5 & \\
\hline & Moulouya & $<0.0001^{\star *}$ & $<0.0001^{\star \star}$ & 7.5 \\
\hline \multirow[t]{3}{*}{$\operatorname{RSB}\left(H=21.65^{\star \star}\right)$} & Tensift & 6.5 & & \\
\hline & Oum er Rbia & $0.03^{*}$ & 6.5 & \\
\hline & Moulouya & 0.002 & $<0.0001^{* *}$ & 5.5 \\
\hline
\end{tabular}


Appendix 2.- Osteological features.

Apéndice 2.- Carcaterísticas osteológicas.



Appendix 2-1.- Dorsal view of the skull of the populations under study. A: Tensift population (N'Fiss River), SL $135.8 \mathrm{~mm}$. B: Oum er Rbia population (Chbouka river), SL $126.5 \mathrm{~mm}$. C: Moulouya population (Moulouya River), SL $139 \mathrm{~mm}$. D: Syntype of Barbus nasus, SL 108.7 mm. Etm: ethmoid bone; fr: frontal.

Apéndice 2-1.- Vista dorsal del cráneo de las poblaciones estudiadas. A: población del Tensift (Río N'Fiss), SL 135,8 mm. B: población del Oum er Rbia (Río Chbouka), SL 126,5 mm. C: población del Moulouya (Moulouya River), SL 139 mm. D: Sintipo de Barbus nasus, SL 108,7 mm. Etm: ethmoid; fr: frontal.



Appendix 2-2.- Frontal view of the skull of the populations under study. A: Tensift population (N'Fiss River), SL $135.8 \mathrm{~mm}$. B: Oum er Rbia population (Chbouka river) showed a short and wide kinethmoid bone, SL $126.5 \mathrm{~mm}$. C: Moulouya population (Moulouya River), SL 139 mm. D: Syntype of Barbus nasus, SL $108.7 \mathrm{~mm}$. E: Syntype of Barbus nasus, SL $81.5 \mathrm{~mm}$. Etm: Ethmoid bone; Kim: Kinethmoid bone; Pmx: Premaxilla. Arrows show the width of kinethmoid bone.

Apéndice 2-2.- Vista frontal del cráneo de las poblaciones estudiadas. A: población del Tensift (Río N'Fiss), SL 135,8 mm. B: la población del Oum er Rbia (Río Chbouka) mostró un hueso kinetmoides corto y ancho, SL 126,5 mm. C: población del Moulouya (Río Moulouya), SL $139 \mathrm{~mm}$. D: Sintipo de Barbus. nasus, SL 108,7 mm. E: Sintipo de Barbus nasus, SL 81,5 mm. Etm: Etmoides; Kim: Kinetmoides; Pmx: Premaxilar. Las flechas muestran la anchura del kinetmoides.

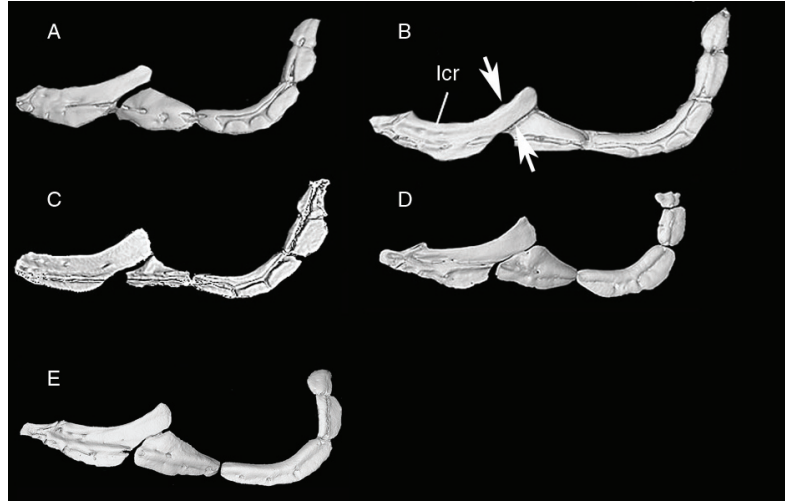

Appendix 2-3.- Infraorbital bones of the studied populations. A: Tensift population (N'Fiss River), SL $135.8 \mathrm{~mm}$. B: Oum er Rbia population (Chbouka river), SL $126.5 \mathrm{~mm}$. C: Moulouya population (Moulouya River), SL $139 \mathrm{~mm}$. D: Syntype of Barbus nasus, SL 108.7 mm. E: Syntype of Barbus nasus, SL $81.5 \mathrm{~mm}$. Lcr: Lacrymal. Arrows show the width of lachrymal manubrium.

Apéndice 2-3.- Huesos infraorbitarios de las poblaciones estudiadas. A: población del Tensift population (Río N'Fiss), SL 135,8 mm. B: población del Oum er Rbia (Río Chbouka), SL 126,5 mm. C: población del Moulouya (Río Moulouya), SL 139 mm. D: Sintipo de Barbus nasus, SL 108,7 mm. E: Sintipo de Barbus nasus, SL $81,5 \mathrm{~mm}$. Lcr: Lacrimal. Las flechas muestran la anchura del manubrio del lacrimal.

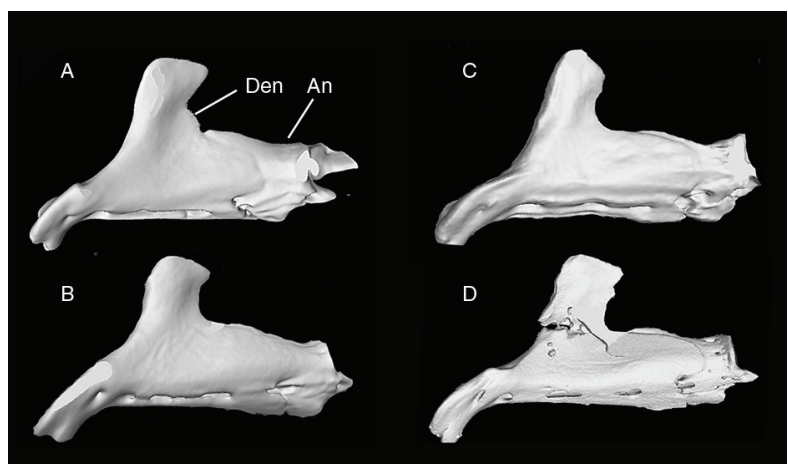

Appendix 2-4.- Dentary bone of the studied populations. A: Tensift population (N'Fiss River), SL $135.8 \mathrm{~mm}$. B: Oum er Rbia population (Chbouka river), SL $126.5 \mathrm{~mm}$. C: Moulouya population (Moulouya River), SL 139 mm D: Syntype of Barbus nasus, SL 108.7 mm. Den: Dentary; An: Anguloarticular.

Apéndice 2-4.- Hueso dentario de las poblaciones estudiadas. A: población del Tensift (N'Fiss River), SL 135,8 $\mathrm{mm}$. B: población del Oum er Rbia (Río Chbouka), SL 126,5 $\mathrm{mm}$. C: población del Moulouya (Río Moulouya), SL $139 \mathrm{~mm}$ D: Sintipo de Barbus nasus, SL 108,7 mm. Den: Dentario; An: Anguloarticular. 


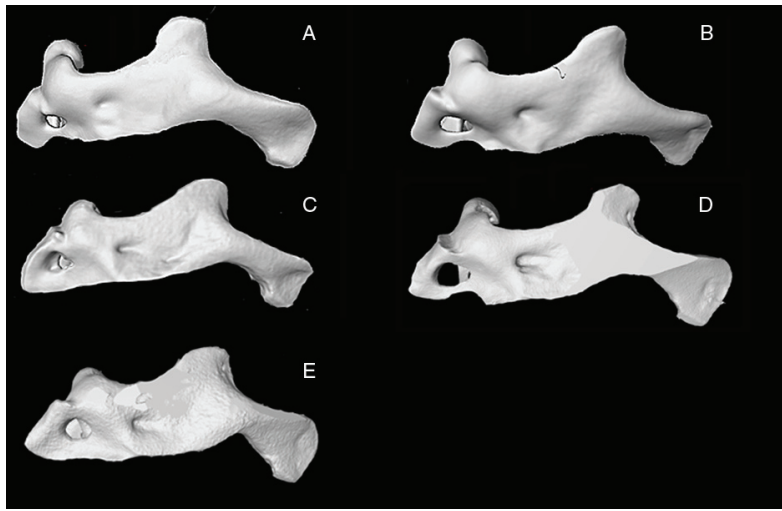

Appendix 2-5.- Maxilla of the studied populations. A: Tensift population (N'Fiss River) showed a short anterior process, SL $135.8 \mathrm{~mm}$. B: Oum er Rbia population (Chbouka River), SL $126.5 \mathrm{~mm}$. C: Moulouya population (Moulouya River), SL $139 \mathrm{~mm}$ D: Syntype of Barbus nasus, SL $108.7 \mathrm{~mm}$ E: Syntype of Barbus nasus, SL $81.5 \mathrm{~mm}$.

Apéndice 2-5.- Maxilar de las poblaciones estudiadas. A: la población del Tensift (Río N'Fiss) mostró un proceso anterior corto, SL 135,8 mm. B: población del Oum er Rbia (Río Chbouka river), SL 126,5 mm. C: población del Moulouya (Río Moulouya), SL $139 \mathrm{~mm}$ D: Sintipo de Barbus nasus, SL 108,7 mm. E: Sintipo de Barbus nasus, SL 81,5 mm.

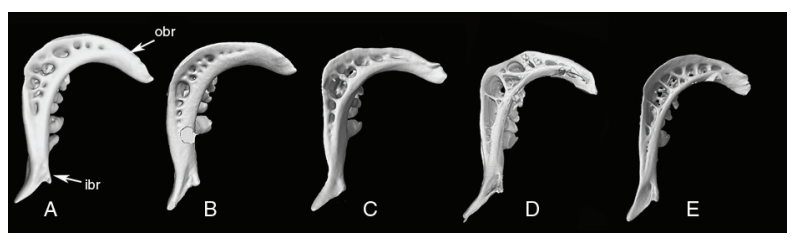

Appendix 2-7.- External view of the pharyngeal teeth of the populations studied. Width of the inner branch between arrows. A: Tensift population (N'Fiss River) showed a flexed superior branch, SL $135.8 \mathrm{~mm}$. B: Oum er Rbia population (Chbouka river) showed a strong inner branch, SL 126.5 $\mathrm{mm}$. C: Moulouya population (Moulouya River) showed a thin pharyngeal bone. SL 139 mm. D: Syntype of Barbus. nasus, SL $108.7 \mathrm{~mm}$. E: Syntype of Barbus nasus, SL $81.5 \mathrm{~mm}$. ibr: Inner Branch. obr: Over branch.

Apéndice 2-7.- Vista externa de los dientes faríngeos de las poblaciones estudiadas. Anchura de la rama interna entre flechas. A: población del Tensift (Río N'Fiss) mostró una rama superior flexionada, SL 135,8 mm. B: población del Oum er Rbia (Río Chbouka) mostró una rama interna robusta, SL 126,5 mm. C: población del Moulouya (Río Moulouya) mostró un hueso faríngeo delgado, SL $139 \mathrm{~mm}$. D: Sintipo de Barbus nasus, SL 108,7 mm. E: Sintipo de Barbus nasus, SL 81,5 $\mathrm{mm}$. ibr: Rama interna. obr: Rama superior.



Appendix 2-6.- Pharyngeal teeth of the populations studied. A: Tensift population (N'Fiss River) showed 5 teeth in the external row, 3 in the middle, and 2 in the inner row, SL 135.8 . B: Oum er Rbia population (Chbouka river) showed 4 teeth in the external row, 3 in the middle, and 2 in the inner row, SL $126.5 \mathrm{~mm}$. C: Moulouya population (Moulouya River) showed 4 teeth in the external row, 2 in the middle, and one in the inner row, SL 139 mm. D: Syntype of Barbus nasus showed 4.3.2 pharyngeal teeth, SL $81.5 \mathrm{~mm}$.

Apéndice 2-6.- Dientes faríngeos de las poblaciones estudiadas. A: población del Tensift (Río N'Fiss) mostró 5 dientes en la fila externa, 3 en la del medio y 2 en la fila interna, SL 135,8 mm. B: población del Oum er Rbia (Río Chbouka) mostró 4 dientes en la fila externa, 3 en la del medio y 2 en la fila interna, SL 126,5 mm. C: población del Moulouya (Río Moulouya) mostró 4 dientes en la fila externa, 2 en la del medio y una en la fila interna, SL $139 \mathrm{~mm}$. D: Sintipo de Barbus nasus mostró 4.3.2 dientes faríngeos, SL $81,5 \mathrm{~mm}$. 